\title{
Asian Financial Integration: Global or Regional? Evidence from Money and Bond Markets
}

\author{
Aarti Rughoo \\ Hertfordshire Business School, University of Hertfordshire, UK \\ Kefei You* \\ Centre for International Capital Markets, London Metropolitan University, UK
}

February 2015

\begin{abstract}
This paper investigates the degree of global versus regional financial integration in Southeast Asia during the period 2004-2012. We examine integration in the money and bond markets in Asia by employing a covered-interest-parity-based measure of financial integration. The impact of the 2008 financial crisis as well as the recent regional bond initiatives on the integration process of Asian money and bond markets are specifically investigated. Empirically, we adopt the Phillips and Sul (2007) convergence methodology that has not been previously employed to examine the integration process in Asian money and bond markets. We find evidence of both global and regional integration in the money market pre 2008 but once the crisis hit, the process of global integration comes to an abrupt halt. However, regional integration, albeit at a slower pace, is still clearly evident in the post-crisis period. As for the Asian bond market, evidence of both global and regional integration is found but, in comparison, the latter is more convergent post 2008. Regional integration is stronger when interest rates with longer maturity are considered. In addition, we identify some convergent sub-groups of countries and this suggests that a multi-tiered style of convergence is present.
\end{abstract}

Key Words: Asia; Financial integration; Bond market; Money market; Panel convergence

JEL Classification: F36, G15, C33

*(Corresponding Author) Centre for International Capital Markets, London Metropolitan University, 84 Moorgate, London EC2M 6SQ U.K. Email: k.you@londonmet.ac.uk. Phone: +44 (0)20 73201520. 


\section{Introduction}

Since the financial crisis in the late 1990s, financial cooperation within the Asian region is primarily centred around regional financial forums, including the Association of Southeast Asian National Plus Three $(\mathrm{ASEAN}+3)^{1}$ and the Executive Meeting of East Asia-Pacific Central Banks (EMEAP). Several regional initiatives, including the Chiang Mai initiative (CMI) and the Asian Bond Market Initiative (ABMI) were put in place in 2000 and 2003 respectively to strengthen regional cooperation and integration. Under the CMI, a regime of regional emergency liquidity provision through bilateral swap arrangements was established while since the endorsement of the ABMI, local currency-dominated bond markets in the region have achieved remarkable growth in terms of size and diversity of issuers. The ASEAN+3 Finance Ministers' meeting in May 2008 agreed on a new ABMI Roadmap setting out tasks to further develop the regional bond market in Southeast Asia. At the same time, cross-border trade and investment within the Asian region have developed at an astonishing pace since the 1990s, which, in turn, have spurred on cross-border financial activities. However, despite the efforts of the regional financial forums and a favourable economic environment, researchers have reached varying conclusions in terms of the degree of financial integration within Asia. The debate rests on whether Asia countries are, in fact, more integrated with the world rather than with each other.

Given that financial integration is a multi-faceted and dynamic issue, existing studies have employed various indexes to measure the extent of financial integration. Among existing studies that examining financial integration within Asia, price-based measures have been

\footnotetext{
${ }^{1}$ ASEAN+3 includes the 10 members of the Association of Southeast Asian Nations (Brunei Darussalam, Cambodia, Indonesia, Lao People’s Democratic Republic, Malaysia, Myanmar, the Philippines, Singapore, Thailand, and Vietnam) plus the People's Republic of China, Japan, and South Korea.
} 
widely employed, although many alternative measures have also been examined ${ }^{2}$. A review of existing literature employing price-based measures reveals the following five issues that we intend to address in our study. First, very few studies employ the covered interest parity (CIP) condition, despite the fact that it requires fewer underlying assumptions than uncovered interest parity (UIP) and real interest parity (RIP). Specifically, as suggested by Kim and Lee (2012), the CIP-based measure of financial integration allows one to examine whether the rate of return of comparable financial assets across countries are equalised after factoring in exchange rate. As such, it is generally a more appropriate measure of financial integration. A second worth noting fact is that, although the Asian bond market has grown substantially in the past decade (see Figure 1) and it is an important part of Asia's integration process, very few empirical studies have been conducted on this market to analyse the issue of financial integration in Southeast Asia. Third, we find that there is lack of comparison on the level of financial integration among markets that factor in variables with different maturities. Often the short-term interest rates are more responsive to changes in liquidity while longer-term interest rates are more responsive to economic fundamentals. Therefore, it would be interesting and informative to examine whether maturity duration affects the level of financial integration. Fourth, the 2008 global financial crisis and recent regional bond initiatives are likely to affect the level of liquidity in the money market and promote the development of Asian bond market, respectively. However, there is no empirical paper that analyses the impact of these two events on the process of Asian financial integration in the context of global versus regional integration. Last but not least, from a methodological perspective, we find that existing studies often employ methods that do not fully capture the dynamics of the integration process. For instance, we do not know whether countries within the Asian group

\footnotetext{
${ }^{2}$ See Section 2 Literature Review for a discussion of price-based measures and alternative measures of financial integration.
} 
are forming sub-groups that are integrating at different speeds, irrespective of whether integration exists for all group members as a whole.

\section{$<$ Insert Figure 1 $>$}

Therefore, our study intends to address the above gaps in the literature by examining the CIP condition in both the short-term money market and the medium-term bond market ${ }^{3}$. The bond market is our prime interest due to its fast expansion in recent years and the lack of relevant existing empirical literature. We consider interbank lending rates in the money market as indicators of the short-term rates. The interbank lending rate is chosen not only due to its short-term characteristic, but also because it is typically the most liquid and well-developed in emerging markets (Cheung et al., 2005). We employ the recently developed panel convergence methodology by Philips and Sul (P\&S) (2007) to provide fresh evidence on the impact of the recent financial crisis as well as the 2008 new ABMI Roadmap on the process of 1) global integration and 2) regional integration of the Asian financial markets. It is worth pointing out that the P\&S methodology is aptly suited for our analysis as it provides an empirical modelling of long run equilibria within a heterogeneous panel. This method would not only reveal whether any convergence is present within the Asian financial markets or globally but the clustering methodology will, in turn, detect whether any specific sub-groups of countries are converging or diverging.

The rest of the paper is organised as follows. Section 2 provides a literature review and highlights several issues in existing studies. Section 3 introduces the CIP condition. Section 4 outlines the P\&S convergence tests. Section 5 presents data source and variable measurement.

\footnotetext{
${ }^{3}$ Initially we intended to also include long-term (e.g. three-, five-, and ten-year) government bond yields in our investigation. However, data for the corresponding forward rates are not available for most countries included in our sample. Hence our study focuses on the medium-term (i.e., one year and two year) bond yields.
} 
Section 6 reports and analyses the empirical findings while the final section concludes and discusses policy implications.

\section{Literature Review}

Given that financial integration is a multi-faceted and dynamic issue, existing studies have employed various indexes to measure the extent of financial integration. Generally speaking, there are three categories of financial integration measures. The first involves price-based measures. These measures are largely embodied in the interest parity conditions in the money market, including covered interest rate parity (CIP), uncovered interest parity (UIP) and real interest rate parity (RIP), as well as co-movements in assets returns of stock and bond markets. The CIP relationship is a popular measure of testing for financial integration as in the absence of risk differences and market shocks, there should be equality between the interest rate differential and the forward exchange rate premium, hence signalling financial integration. Kearney and Lucey (2004) refer to the price-based measures as a direct measure since it invokes the law of one price whereby unrestricted international capital flows would lead to an equalisation of the rates of return across countries. The second category refers to volume-based measures. Two widely used measures in this category include savingsinvestment correlations pioneered by Feldstein and Horioka (1980) and consumption correlations (e.g., Bayoumi, 1997; de Brouwer, 1999). The third category is broadly based on regulatory or institutional factors. Often capital controls and legal restrictions such as restrictions on foreign equity holdings are employed to assess the extent of financial integration (e.g., Grilli and Milesi-Ferretti, 1995; Magud and Reinhart, 2006).

Alternatively, Kearney and Lucey (2004) categorise two broad categories of financial integration - direct and indirect measures. The former refers to measures based on the law of one price, namely CIP, UIP and RIP as mentioned above. The indirect measures include two 
approaches with the first one invoking the concept of international capital market completeness (Stockman, 1988) and the second is based on Feldstein and Horioka's (1980) savings-investment relation. Since it is now recognised that the correlation between savings and investment does not have implications for the degree of mobility of international capital flows, Kearney and Lucey (2004) conclude that the two most useful definition of financial integration are CIP and capital market completeness. Baele et al. (2004) consider three categories of financial integration measures - price-based measures, news-based measures and quantity-based measures. The second category of measures tests whether returns on assets across countries are influenced by local or world-wide news (see Baltzer et al. (2008) for a similar definition). The price movements of a benchmark asset are typically used as a proxy for global news. The logic behind the first two categories is the law of one price. The third category employs information on the ease of market access to measure the extent of financial integration,

It is also worth pointing out that some more recent price-based measures have emerged since but are mostly applied to capital markets. For instance, Volosovych $(2011,2013)$ have introduced an integration index in the context of capital market integration using a dynamic principal component analysis. This approach has also been applied by Donadelli and Paradiso (2014).

We now review previous studies that analyse the financial integration process of the Southeast Asian markets. We focus on the price-based measures given that they are the most widely employed and appropriate indicators in this context. Regarding studies on the Asian money market, recently, Tang (2011) examines the UIP relationship employing panel cointegration, fully modified OLS and the dynamic OLS tests. Tang (2011) finds no evidence that the ASEAN-5 countries (Indonesia, Malaysia, Philippines, Singapore, and Thailand) are integrated with the US except for Singapore. Also examining the UIP condition for a smaller 
group of Asian countries (China, Hong Kong and Taiwan), Cheung et al. (2005) use augmented Dickey Fuller-General Least Square (ADF-GLS) test and find that the deviations are shrinking in absolute value over time. On the other hand, adopting the RIP relationship and using panel unit root tests, Baharumshah (2005) and Holmes et al. (2011) find evidence of regional financial integration for Asian economies, whilst Singh and Banerjee (2006) do not. In the context of the CIP relationship, Kim and Lee (2012) construct daily covered interest differential between Asian money market and the US and between Asia and Japan to gauge the extent of Asian financial market's global and regional integration respectively. They compare the mean of these two sets of differentials and find that the latter set is bigger. Thus they conclude that Asian financial integration is more global than regional. Qin et al. (2007) empirically examine monthly covered interest differential between the Asian money market and the US using the Dynamic Factor Error Correction Model (DF-ECM). Their empirical findings suggest that the degree of money market integration is still very low ${ }^{4}$.

In contrast with studies on Asian money markets, there are far fewer studies that examine the Asian bond market. Vo (2009) and Calvi (2010) are two such studies that analyse the integration of Asian bond market for selected Asian economies by applying cointegration methods. The former finds weak evidence of integration while the latter finds the absence of an integrated relationship. Park and Lee (2011), on their part, analyse country specific sensitivity of the returns of bond markets to regional or global shock. They find that Asian's regional local currency bond markets are neither regionally nor globally integrated. Using high frequency daily Asian bond market yields, Fung et al. (2008) construct several indicators for measuring bond market integration and their indices suggest Asian bond markets are only weakly integrated.

\footnotetext{
${ }^{4}$ Without referring to any interest parities, Anoruo et al. (2002) and Ibrahim (2009) examine the Asian money market interest rates directly using cointegration methods and find evidence of full and partial integration, respectively.
} 
Our review of the literature highlights the following issues. The first concerns the price indicators used to measure Asian financial integration. UIP assumes rational expectation and the test for the UIP is a joint test for the CIP and the currency risk premium; RIP implies that both Purchasing Power Parity (PPP) and UIP simultaneously hold. Hence when UIP and RIP do not hold, the underlying reason is ambiguous. As pointed out by Cavoli et al. (2006), although the CIP is a generally preferred measure of financial integration, the literature employing CIP for Asian economy is limited, which is most likely due to the lack of data on forward foreign exchange markets. Kearney and Lucey (2004) and Kim and Lee (2012) also suggest that CIP is the more appropriate price based measure of financial integration. To our knowledge, there is only one study that empirically examines the CIP condition for Asian money market, i.e. Qin et al. (2007), and we are not aware of any analysis of the CIP for Asian bond markets.

Second, although the Asian bond markets have experienced drastic growth in the past decade (Figure 1), studies that study the bond market to empirically examine the issue of financial integration in Asia is sparse and none adopts the CIP condition. Looking at Figure 1, since year 2000, the total amount of local currency (LCY) bonds outstanding in Southeast Asia (excluding Japan) has increased by almost tenfold from 835.9 to 7625.9 billion USD. The figures are even bigger when Japan is taken into account but with a smaller speed of growth. Therefore, given the impressive expansion of the Asian regional bond market, a careful investigation of Asian financial integration via the bond market is warranted.

Third, compared with short-term interest rates which are largely determined by the level of liquidity, medium- to long-term interest rates are more prone to be influenced by economic fundamentals. For instance, a European Central Bank’s recent assessment of financial integration in Europe (European Central Bank, 2013) suggests that divergent sovereign bond yields in European countries reflects diverging country fundamentals, such as increasing 
differences in the perceived sustainability of balance of payment and sovereign fiscal positions. Therefore, we examine both short-term money market and medium-term bond market in Asia to evaluate whether interest rate of various maturity durations show different patterns of convergence since the underlying determinants of these interest rates are different. As discussed by Baltzer et al (2008), bond and money markets have sufficiently comparable cash flow and risk characteristics to warrant price-based tests of financial integration. Following Cheung et al. (2005), the interbank lending rate is employed as an indicator of the money market rate.

Fourth, the regional financial integration within Asia is often compared with Asia's integration with the global market (e.g., Eichengreen and Park, 2004; Poonpatpibul et al., 2006; Kim et al., 2006; Park and Lee, 2011; Kim and Lee, 2012). Almost all studies suggest that the latter form of integration is stronger. We intend to bring new evidence on this issue by examining whether the recent financial crisis altered the pattern of financial convergence in Asia, both regionally and globally, in the money market. As suggested by Rigg and SchouZibell (2009), the impact of the crisis on the Asian money market is comparable to the effect observed in international markets despite higher levels of savings and liquidity in its banking system. Moreover, we also investigate the impact of the 2008 new ABMI Roadmap on Asian bond market integration.

Fifth, the classic methods used in above mentioned studies include unit root, regression and cointegration tests. Oftentimes, these methods do not capture the dynamic of the integration process. For instance, compared to cointegration tests, the Phillips and Sul (P\&S) procedure does not require any assumptions regarding stationarity and allows for cases where individual series may be transitionally divergent. Hence, in the event that variables may be converging but the speed of convergence is too slow to reflect cointegrated behaviour, the P\&S method will still detect this co-movement and convergence. In addition, by allowing for both 
common and individual heterogeneity, the $\mathrm{P} \& \mathrm{~S}$ method is preferable to the popular beta and sigma convergence tests as the speed and degree of convergence can both be analysed. Some recent studies, employing other methods, are also capable of capturing the dynamics of the integration process among countries. For instance, following Volosovych (2011, 2013), but looking at both country and industry level, Donadelli and Paradiso (2014) employ a principal component analysis (PCA) to examine the dynamics of the financial integration process across equity markets in one global emerging region referred to as 'Emerging' and three emerging sub-regions (Asia, Eastern Europe, and Latin America) during the period 19802012. Compared with the PCA, the P\&S method enables us to capture the dynamics of the integration process in South East Asia in a unique manner. Specifically, irrespective of whether integration exists for all group members as a whole, countries within the Asian group may be forming sub-groups that are integrating at different speeds, and the P\&S method is able to detect such sub-groups ${ }^{5} .6$.

\section{Covered Interest Differentials}

Covered interest parity (CIP) states that if financial markets are perfectly integrated and domestic and foreign financial assets are perfect substitutes, the difference between the spot rate and the forward rate would be equivalent to the interest rate differential between domestic and foreign countries. Investors would certainly not tolerate a lower domestic return in the absence of capital controls (Frankel, 1991). Hence any deviations from the CIP condition, or non-zero covered interest differentials would indicate restriction on cross-border capital movements. Although other factors, such as differences in investment risks on default and temporary liquidity problems, can also cause deviations from CIP, in general non-zero

\footnotetext{
${ }^{5}$ Some other studies that analyse the dynamics of the integration process include Pukthuanthong and Roll, (2009), Ip-Wing et al., (2010) and Donadelli (2013).

${ }^{6}$ For applications of the P\&S method in the context of financial integration in Europe, see Rughoo and Sarantis (2012; 2014), Caporale et al (2009), Antzoulatos et al (2008), Higson et al (2009) and Fischer (2009).
} 
covered interest differential indicates the degree of financial market integration (Kim and Lee, 2012). Formally, the CIP can be stated as follows:

$$
r_{t}-r_{t}^{*}={ }_{t} f p_{t+1}
$$

where $r_{t}$ and $r_{t}^{*}$ are domestic and foreign interest rate, respectively, and ${ }_{t} f p_{t+1}$ is the forward premium/discount of the foreign currency for the next period. Exchange rate is measured as domestic currency per foreign currency.

Based on the CIP and following Kim and Lee (2012), we obtain the covered interest differentials (CID) as the interest differential less forward discount/premium;

$$
C I D=\left(r_{t}-r_{t}^{*}\right)-{ }_{t} f p_{t+1}
$$

In our study, we compute CID using US, Japan, and a regional index as our benchmarks (see Section 5 for detailed data source and variable measurement). If Southeast Asian countries are integrated with the US markets, then CID using the US as the benchmark should converge. On the contrary, if these markets are integrated regionally, then convergence should be found in the CID when Japan or the regional index is used as a benchmark.

\section{Methodology - The Phillips and Sul Panel Convergence Tests}

If integration is present within the Asian financial markets, then over time, the covered interest differentials based on the interbank rates and government bond yields should converge. The P\&S panel convergence methodology is ideally suited to test for the level of Asian financial market integration as it is based on a time varying factor representation and therefore allows for both common and individual heterogeneity over time. In comparison to other convergence models such as the widely used concepts of $\beta$ - convergence and $\sigma$ convergence derived from the growth literature (see Barro and Sala-i-Martin, 1991, 1992), this characteristic of the $\mathrm{P} \& \mathrm{~S}$ approach makes it superior to the other convergence tests. In addition, as indicated by Islam (2003), $\beta$-convergence and $\sigma$-convergence are more suitable in 
the context of growth model and there are a few potential problems when empirical tests of convergence are conducted, especially in cases where some countries are converging while others are not (see Bernard and Durlauf (1996)). With regards to the current literature on Asian financial integration, the convergence tests rely mostly on cointegration and unit root tests. As discussed by Phillips and Sul (2009), if the speed of convergence is slower than the speed of divergence, then the conventional cointegration tests will not detect the asymptotic co-movement due to low power.

\subsection{The logt regression test}

Panel data for a variable $X_{i t}$ can normally be decomposed into two components comprising systematic components, $g_{i t}$, and transitory components, $a_{i t}$, as follows:

$$
X_{i t}=g_{i t}+a_{i t}
$$

P\&S calculate the time-varying loadings, $g_{i t}$, by reformulating Equation (3) such that common and idiosyncratic components are separated :

$$
X_{i t}=\left(\frac{g_{i t}+a_{i t}}{\mu_{t}}\right) \mu_{t}=\delta_{i t} \mu_{t} \text { for all } i \text { and } t \text {, }
$$

$\mu_{t}$ is a single common component and $\delta_{i t}$ is a time varying idiosyncratic element. $\delta_{i t}$ measures the economic distance between the common trend component $\mu_{t}$ and $X_{i t}$. To test whether the components of $\delta_{i t}$ are converging, Phillips and Sul (2007) define the transition coefficient as $h_{i t}$ as follows:

$$
h_{i t}=\frac{X_{i t}}{\frac{1}{N} \sum_{i=1}^{N} X_{i t}}=\frac{\delta_{i t} \mu_{i t}}{\frac{1}{N} \sum_{i=1}^{N} \delta_{i t} \mu_{i t}}=\frac{\delta_{i t}}{\frac{1}{N} \sum_{i=1}^{N} \delta_{i t}}
$$


The so-called relative transition parameter $h_{i t}$ measures $\delta_{i t}$ in relation to the panel average at time $t$ and therefore describes the transition path for country $i$ relative to the panel average. P\&S make the distinction between two types of convergence (denoted by $\alpha$ ): conditional convergence (convergence in rates) versus absolute convergence (convergence in levels). Consequently, the null hypothesis of the $\log t$ regression test for conditional convergence is:

$$
H_{0}: \delta_{i}=\delta \text { and } \alpha \geq 0
$$

against the alternative

$$
H_{1}: \delta_{i} \neq \delta \text { for all } i \text { or } \alpha<0
$$

while the null hypothesis for absolute convergence is:

$$
H_{0}: \delta_{i}=\delta \text { and } \alpha \geq 1
$$

Phillips and Sul's (2007) procedure involves three steps, as listed below.

Step 1: The cross sectional variance ratio $H_{1} / H_{t}$ is calculated as follows:

$$
H_{t}=1 / N \sum_{i=1}^{N}\left(h_{i t}-1\right)^{2}
$$

Step 2: The following OLS regression is performed:

$$
\log \left(H_{1} / H_{t}\right)-2 \log L(t)=\hat{a}+\hat{b} \log t+\hat{u}_{t}
$$

where $\mathrm{L}(t)=\log (t+1)$ and the fitted coefficient of $\log t$ is $\hat{b}=2 \hat{\alpha}$, where $\hat{\alpha}$ is the estimate of $\alpha$ in $\mathrm{H}_{0}$. The data for this regression starts at $t=[r \mathrm{~T}]$ with some $\mathrm{r}>0$. Based on the results of their Monte-Carlo simulations, Phillips and Sul (2007) recommend $r=0.3$.

Step 3: A one-sided $t$ test of null $\alpha \geq 0$ using $\hat{b}$ and a standard error estimated using a heteroskedasticity and autocorrelation consistent (HAC) estimator. The test statistic $t_{\hat{b}}$ is normally distributed and hence at the 5\% level, the null hypothesis of convergence is rejected if $t_{\hat{b}}<-1.65$.

\subsection{Club convergence algorithm}


Following Phillips and Sul's (2007) argument that a strict rejection of the null of convergence may not necessarily rule out the existence of sub-group convergence within the panel, the authors have developed a club convergence algorithm to detect such units of clusters. In the scope of this paper, this methodology will bring new insight into the convergence process within the Asian financial markets by revealing whether clusters of convergence are present. If present, then the relationship within the clusters based on economic or structural characteristics can be further explored.

Phillips and Sul (2007) clustering algorithm is based on repeated $\log t$ regressions and follows a step-wise approach whereby in step 1 , the $X_{i t}$ series in the panel are ordered according to the last observation, $X_{i T}$. In Step 2, a core group is formed by selecting the first $k$ highest panel members to form the subgroup $\mathrm{G}_{\mathrm{k}}$ for some $\mathrm{N}>k \geq 2$ and the convergence test statistic $t_{\hat{b}}(k)$ is calculated for each $k$. The core group size $k^{*}$ is chosen by maximising $t_{\hat{b}}(k)$ under the condition that $\min \left\{t_{\hat{b}}(k)\right\}>-1.65$. Step 3 follows a selection procedure whereby each remaining country is then added separately to the core group and the log $t$ test is run and the country is included in the new club if the corresponding test statistic, $t_{\hat{b}}$ is greater than a chosen critical value, $c^{7}$. The $\log t$ test is then run for this subgroup and if $t_{\hat{b}}$ is $>-1.65$, the formation of this subgroup is completed. Otherwise, the critical value c is raised and the procedure is repeated. In the final step, the $\log t$ test is run on the group of countries not selected in the previous step and a second club is formed if convergence is identified. If not, steps 1,2 and 3 are repeated on the remaining countries. If no other subgroups can be detected, it can be concluded that the remaining countries diverge.

\footnotetext{
${ }^{7}$ Phillips and Sul (2009) suggest setting $c$ to zero when $\mathrm{T}$ is small to ensure that it is highly conservative. However, for large T, $c$ can be set at the asymptotic $5 \%$ critical value of -1.65 . Given that the number of observations per country in this paper ranges around $50, c$ is set at 0 .
} 


\section{Data Source and Variable Measurement}

Our group of Southeast Asian countries include the 5 core ASEAN countries (Indonesia, Malaysia, Philippines, Singapore, Thailand) plus 3 (China, Japan and South Korea) and Hong Kong. CID values are constructed using Equation (2). As explained earlier, we use interbank lending rates as our measure of interest rates in the money market. The maturity durations are short-term (one-month and three-month) for interbank rates and medium-term (one-year and two-year) for government bond. Forward discounts/premiums are calculated using spot and forward exchange rates where the forward rates have maturities in accordance with that of the interest rates. Due to data limitation, we are not able to include long-term (e.g., three-, fiveor ten-year) government bond yield in our study. For each type of maturity, we use the following three benchmarks to calculate CID:

a) The US as a benchmark

We adjust the interest rate differentials between our nine Southeast Asian countries and the US with the forward premiums of their currencies against the USD.

b) Japan as a benchmark

We adjust the interest rate differentials between our eight (excluding Japan) Southeast Asian countries and Japan with the forward premiums of their currencies against the Japanese Yen.

c) Regional average as a benchmark

According to the World Bank, financial depth captures the importance of financial sector relative to the economy and can be measured by the ratio of domestic credit to private sector to $\mathrm{GDP}^{8}$. In our study, we construct a regional index for interest rates using weights determined by the financial depth of each country. It provides a more accurate indication of the level of financial development of each country than, for instance, using GDP weights directly. For example, Hong Kong and Singapore are two of the most developed financial 
centres in Asia yet their GDP (PPP adjusted) ranks at the bottom (i.e., eighth and ninth) among the nine Southeast Asian countries as per the World Bank, 2012 ${ }^{9}$. The forward discount index is constructed by adjusting the forward discount of each country by the weighted average of the forward discount of the nine countries. Since all exchange rates are measured against the USD, this index measures the relative forward discount of each country's currency against a weighted average of regional currencies. To be consistent, the weights are also determined by the level of financial depth of each country. Finally, interest rate differentials (nominal interest rate of each country minus the regional interest rate index) minus the forward discount index generate the covered interest differentials using regional average as a benchmark.

As for data sources, one-month interbank rate, three-month interbank rate, one-year government bond yield and two-year government bond yield data and corresponding forward exchange rate data for all nine Southeast Asian economies are collected from Bloomberg. All four types of interest rates for the US are also collected from Bloomberg. Spot exchange rate, domestic credit to private sector and GDP data are collected from International Financial Statistics. Data frequency is monthly. Based on data availability, the data span for the covered interest differentials for the four different interest rates are presented below. We divide our panels of interbank rate of the money market into two distinct periods, a pre-crisis period (pre August 2008) and a post-crisis period (September 2008 to December 2012). The collapse of Lehman Brothers in September 2008 is viewed as the harbinger of the ensuing global financial crisis. We divide the sample period for the bond market rates on the basis of the new ABMI Roadmap which was agreed in May $2008^{10}$.

\footnotetext{
${ }^{9}$ http://data.worldbank.org/indicator/NY.GDP.MKTP.PP.CD/countries/order\%3Dwbapi_data_value_2012\%20w bapi_data_value\%20wbapi_data_value-

last?order=wbapi_data_value_2012\%20wbapi_data_value\%20wbapi_data_valuelast\&sort $=$ desc\&display $=$ default

${ }^{10}$ There had been exchange rate regime changes in several Southeast Asian countries during our sample period. For instance, in July 2005, the Chinese Yuan shifted its peg to the USD only to a basket of major currencies (see
} 
a) one-month interbank rate: $2004 \mathrm{~m} 9-2012 \mathrm{~m} 12$

Sub-sample periods: 2004 m9-2008 m8, 2008 m9-2012m12

b) three-month interbank rate: 2004 m9-2012m12

Sub-sample periods: 2004 m9-2008 m8, 2008 m9-2012m12

c) one-year government bond yield: 2005 m6-2012m12

Sub-sample periods: 2005 m6-2008 m4, 2008 m5-2012 m12

d) two-year bond government yield: 2007 m3-2012 m12

Sub-sample periods: 2007 m3-2008 m4, 2008 m5-2012 m12

The CID data of the above four rates are further plotted in Figures 2a-5c (see Appendix A), respectively and the descriptive statistics are provided in Tables 1a-1d (see Appendix B). For all interbank rates (Figures 2a-3c), we observe large changes in CID immediately after 2008m8. We also observe that the outbreak of 2008 financial crisis created turbulence in the one-year bond yield (Figures 4a-c), although when compared with the corresponding oneand three-month interbank rates, there had been fewer spikes and the bands of variations are overall smaller. It is interesting to note that when we move to the longer-term interest rates, i.e., two-year bond yield (Figures 5a-c), we find the overall patterns of movement are different from the interbank rates and the one-year bond yield. Specifically, China and Indonesia often occupy the higher and lower yields, respectively. Countries in between have much smoother yield movements compared with countries in Figures 2a-4c. Much fewer countries exhibit sharp changes in yields after the onset of 2008 financial crisis. Instead, we observe that reductions in yields in the majority of countries have occurred in the early 2008, echoing the new ABMI Roadmap agreement in May 2008.

You and Sarantis (2011, 2012a,b) for detailed discussion of this shift). Naturally one would suggest that an alternative way to divide the sample is to use the dates of exchange rate regime shifts. However, this method may be practically infeasible as these regime shifts occurred at different times and more importantly, there had been significant disagreement among researchers regarding the De Facto exchange rate regimes classification in middle-income countries (emerging markets) and low-income (developing) countries (Eichengreen and RazoGarcia, 2011). 


\section{Results}

\subsection{Phillips and Sul (2007) convergence results for the money market}

Following Phillips and Sul's (2007) recommendation, we apply the Hodrick and Prescott (1997) filter ${ }^{11}$ to remove the cycle component of each series before running the convergence test on the interbank and bond data sets. The test results are displayed in Tables 2-7. For the one-month and three-month interbank CID against the US (Table 2), we find convergence in the pre-crisis period (2004-2008) for both types of interbank rates but this convergent behaviour stops abruptly once the crisis started as no convergence is observed for the 2008 to 2012 period. Furthermore, during the pre-crisis period, the speed of convergence seems to vary with the maturity of the interbank rates. Weak convergence is observed for the onemonth interbank CID ( $\hat{b}=-0.36)$ and the null of conditional convergence; i.e., convergence in rates cannot be rejected as $\hat{b}<2$. On the other hand, the speed of convergence parameter for the 3-months interbank spreads is greater than $2(\hat{b}=5.2)$, so that the null of absolute level convergence cannot be rejected during 2004-2008.

\section{$<$ Insert Table 2>}

Against Japan's rate, we do not find any convergence for both types of interbank rates either before or after 2008 (Table 3). On the other hand, when we test for regional convergence against the size-weighted average, we find convergence in the rate of change for the onemonth and three-month interbank CID in both the pre- and post-crisis periods (Table 4). The speed of convergence is notably stronger for the pre-crisis period ( $\hat{b}=1.3 ; 1.9)$ while post

\footnotetext{
${ }^{11}$ The HP filter is chosen as it is an optimal filter in cases where the goal is to analyse the behaviour of a variable across series as opposed to relying on it purely as a detrending method. The HP filter can remove more information on the data than may be desirable but it is a suitable filter if the objective is to measure long term equilibria. Higher frequency data require a higher value for the smoothing parameter, lamda so we set lamda at 14400 , as suggested by the literature.
} 
2008, the magnitude of convergence is much slower $(\hat{b}=0.25 ; 0.04)$. Our results suggest that prior to the global financial crisis, the Asian money markets were strongly integrated with the US market as the interbank spreads against the US rate were converging to the same level. Indeed as reported by Bank of International Settlement (2008), the growth rate in the international interbank market, particularly in the US Dollar segment, had been accelerating before the crisis. However, in the post 2008 period, a complete reversal in the integration process with the US market is observed and this is attributed to the dramatic impact of the global financial crisis. As widely reported, after August 2007, the interbank markets around the world were severely impaired with banks choosing to hoard cash due to sharp rises in perceived counterparty risk, volatility and asymmetric information (see Acharya and Merrouche, 2010; Allen et al, 2010). Given the integral role played by the interbank market in the functional of financial markets, it is not surprising that the result of heightened financial stress spilling over from the US and the subsequent freezing up of the money markets have halted the integration process with the US market post 2008. Our results also show that regional integration within the Asian interbank market is clearly present throughout the entire sample period and is running in parallel with global integration for the pre 2008 period. This finding is in contrast to conclusions made by previous studies that test for regional integration versus global integration in Asia (i.e., Eichengreen and Park, 2004; Poonpatpibul et al., 2006; Kim et al., 2006; Park and Lee, 2011; Kim and Lee, 2012). It is worth mentioning that among these studies, only Park and Lee (2011) cover the post-crisis period 2008-2009.

$<$ Insert Tables 3 and 4>

\subsection{Phillips and Sul (2007) convergence results for the bond market}


In 2003, in the wake of the 1997 Asian financial crisis, the ASEAN+3 Finance Ministers agreed to promote an Asian Bond Market Initiative (ABMI) to develop the bond market in Asia. Since the launch of the ABMI, it has gone through 3 phases, with the latest being the new ABMI roadmap agreed in May 2008. Consequently, in order to encapsulate the most recent initiatives aimed at promoting a more efficient and liquid Asian bond market as well as the occurrence of the global financial crisis, we test for convergence between the Asian bond markets and the US and within the region in two sample periods, pre and post May 2008, and the results are presented in Tables 5-7.

\section{$<$ Insert Table 5>}

We first look at the one-year government bond CID. For the one-year bond rates against the US (Table 5), we find convergence prior and post 2008 but the rate of convergence is slower post crisis. This could be due to the impact of the crisis which resulted in, among others, a decline in capital flows to Asia and difficulties in raising dollar funds overseas (Shimuzu, 2010). Against Japan's rate (Table 6), interestingly, we find no convergence prior to the crisis but post 2008, slow convergence is detected $(\hat{b}=0.103)$. The positive convergence results can be linked to the steps taken by Japan following the crisis such as the arrangement of a 6 million Yen swap with Asian countries and the setting up of a Market Access Support Facility to guarantee samurai bond issues by Asian governments to a maximum of 500 billion Yen. Shimuzu (2010) reckons that this initiative has been instrumental in promoting crossborder trading within the region. The results for the CID against the size-weighted rate which tests for convergence within the region (Table 7) indicate the presence of convergence in the one-year bond CDI in both prior and post 2008. Stronger results are reported for the period following the renewed Asian bond initiative $(\hat{b}=0.17)$. These results suggest a) that the global crisis has made investors take a more inward-looking view and b) recent achievements 
through the ABMI such as the establishment of the Credit Guarantee and Investment Facility which guarantees bond issues within the region and the setting up of the ASEAN+3 Bond Market Forum have been successful.

$<$ Insert Tables 6 and 7>

For the two-year bond CID, we find no evidence of global (against the US) or regional integration (against Japan and weighted regional average) prior to 2008. However, post 2008, we find strong convergence in levels against both the US rate and the weighted regional average while convergence in rates is noted against Japan. In particular, we also note that the

magnitude of convergence is stronger when testing against the regional index $(\hat{b}=7.7)$ compared to the global index, i.e. the US rate $(\hat{b}=2.4)$. These results suggest that the ABMI has indeed spurred on further integration within the region.

A further comparison across maturities (one-month, two-month, one-year, two-year) reveals that, regional convergence in the post 2008 period is evident in all four types of maturities. More importantly, we also observe the strongest convergence results $(\hat{b}=7.7$ in Table 7) occurs when the rates with the longest maturity (i.e., 2-year bond yield) is considered. Therefore, our results suggest that there is consistent evidence of financial integration within the Southeast Asian region and that such regional integration is stronger in rates with longer maturity durations where economic fundamentals play a bigger role in determining these rates.

\subsection{Club convergence results}

Phillips and Sul (2007) argue that group convergence may not be identified when the logt test is applied because of the presence of divergence members in the panel and that clubconvergence may still be possible. Therefore, the next step in the analysis is the application 
of the Phillips and Sul (2007) clustering algorithm test which would potentially identify countries that are converging within different clusters and also identify divergent members. The results are presented in Table 8.

Looking at the interbank and bond rates against the US, the club convergence results underpin the earlier group log-t results. Specifically, for the interbank market, convergence is noted prior to the financial crisis but not after. For the bond market, club convergence is observed for both pre and post 2008 periods. Interestingly, for the two-year bond rates, 2 clubs are identified with China, Singapore, Japan and Philippines making up the first club with a stronger convergence parameter $(\hat{b}=1.5)$. The remaining 5 countries make up the second club $(\hat{b}=0.82)$.

\section{$<$ Insert Table 8>}

The club convergence results against Japan's interbank rate sharply contrast with the logt results as we find several clusters of convergent countries, especially for the pre 2008 period, which further explains why a full panel convergence is not detected. As for the bond rates, we find one convergent club in the post 2008 period for the two-year rates and two to three clubs in other cases. In particular, we note that Indonesia and Philippines consistently form one club across the whole period for both the money and bond markets. This seems to suggest that geographical proximity is the driving factor here. Against the weighted average, convergent clubs are identified for both the money and bond markets and interestingly, the countries that were diverging pre-2008 became convergent post-2008. We only find some divergent countries post-2008 for the one-year bond market.

In addition, the following observations are noted. Firstly, across both the global and regional money market, we find that China, Thailand, Malaysia, South Korea and Hong Kong often belong to the same groups; whether converging or diverging. Secondly, Singapore and Japan always cluster together when Japan is included in the sample. Such patterns of grouping may 
reflect similar level of development in their banking sector for some countries (e.g. Indonesia and Philippines, Singapore and Japan) and varied stage of development for others (e.g. China, Thailand, Malaysia, South Korea and Hong Kong). The exclusion of Hong Kong at times from the group comprising Singapore and Japan may be reflecting there different exchange rate regimes, namely a crawling peg in Hong Kong and a floating regime in Singapore and Japan. Thirdly, we find similar patterns for the bond market. However, Singapore now often moves in tandem with Hong Kong. Japan is often either one of the faster convergence countries (especially with the US) or one of the divergent countries. Such pattern may reflect the more developed bond market in Singapore and Hong Kong while we note that Japan's participation in the Asian bond market scheme only started in recent years.

\subsection{Transition curves}

The third element of the Phillips and Sul (2007) methodology is the analysis of the transition coefficients of each country's data series which illustrate the relative transition paths for each country vis-à-vis the cross-section panel average. Convergent behaviour is associated with a clustering of the curves towards the value of one and divergent behaviour is shown as a movement away from one. Figures $6 a-6 d$ illustrate the transition curves ${ }^{12}$ for the 1 -month and 3-months interbank rates and the 1-year and 2-year bond yields for the whole sample period. The behaviour of the transition curve strongly underline the club convergence results discussed in the previous section, i.e., we can observe considerable diverse behaviour in the transition paths prior to 2008 but a clear clustering of all the transition curves (except for those of Indonesia and Philippines) is noted post-2008. The post-2008 convergent trend is noticeably more pronounced for the 1-month interbank rates as well as the 2 year-bond yields.

\footnotetext{
${ }^{12}$ We opt to illustrate the 1-month, 3-months interbank rates and 1-year and 2-year bond yields transition curves for the CID against the weighted average only as the results for the club convergence tests show some broadly similar patterns across the three main datasets.
} 
As for the curves for Indonesia and Philippines, they are clearly divergent, confirming the club-convergence results whereby the two countries often form one club.

$<$ Insert Figures 6a and 6b>

Overall, the results obtained for the club convergence tests and transition coefficients emphasise the earlier observations from the logt results that the global financial crisis has brought about closer regional integration among the 9 Asian countries whilst, at the same time, reversing the trend in global integration from convergent to divergent or weaker convergence.

$<$ Insert Figures 6c and 6d $>$

\subsection{Robustness checks}

To test for the robustness of our results, we also apply the $\beta$-convergence test that models the 'catch-up effects' by regressing the growth rate of a variable on the initial level. The $\beta$ convergence test is drawn from the growth literature (see Barro and Sala-i-Martin (1991)) and has been applied in studies testing for banking integration in Europe (see Vajanne (2007), Casu and Girardone (2010), Weill (2009)). As far as we are aware, the $\beta$-convergence methodology has not previously been applied to test for convergence in the Asian money and bond markets. We run the following equation to estimate $\beta$-convergence for our panel of CID on interbank and bond rates for the pre 2008 and post 2008 periods.

$$
\operatorname{Asia}_{i, t}-\text { Asia }_{i, t-1}=\alpha+\beta A s i a_{i, t-1}+\sum_{i=1}^{n} D_{I}+\varepsilon_{i, t}
$$

where Asia $_{i, t}$ is the CID of country $i$ in month $t, A s i a_{i, t-1}$ is the CID of country $i$ in month t1. $D_{i}$ represents the country dummies and incorporate fixed effects to isolate the country effects. $\alpha$ and $\beta$ are the parameters to be estimated. $\beta$-convergence is present if the coefficient $\beta$ is negative, which implies that the difference between $A s i a_{i, t}$ and $A s i a_{i, t-1}$ is as large as the difference from the initial levels. The results are tabulated in Table 9. For all the 
categories of money market rates and bond rates, convergence is present both pre 2008 and post 2008 except for the pre-crisis one-year bond CID against the US.

$<$ Insert Table 9>

These results broadly agree with our earlier results based on the Phillips and Sul methodologies but some key differences are also noted. For instance, the logt test does not find any convergence in the money market against the US after the financial crisis while the null of convergence under $\beta$-convergence cannot be rejected. Given the severity of the impact of the global crisis on the money market, this latter finding is puzzling and questionable. In addition, the $\beta$-convergence test may conceal the existence of sub-group convergence. For instance, in the case of interbank rate based CID against Japan, the club convergence test reveals the presence of convergent sub-clubs in spite of the evidence of no convergence for the full panel. Such information would not have been provided by the $\beta$-convergence test. As argued by Islam (2003), the $\beta$-convergence is uninformative on the speed of convergence as it only computes the mean reversion for the panel units. There is no indication on the behaviour of individual countries across the panel and no allowance for variation over time. On the other hand, the P\&S method allows for individual heterogeneity which can evolve over time. Given the context of this study where country-specific characteristics are inherent, the P\&S method is therefore better suited and as such, we attribute more weight to the findings under the P\&S model.

\section{Conclusions and Policy Implications}

Our study examines the process of global versus regional financial integration in Southeast Asia through its money and bond market. We employ the CIP condition that has not been examined for Asian bond market and rarely for Asian money market. We specially assess the impact of the recent 2008 financial crisis and the new ABMI Roadmap on the integration 
process in the money and bond market, respectively. A comparison between the two markets enables us to evaluate how financial markets, with interest rates of different maturities, behave in the context of the convergence process in Asia. We apply the innovative panel convergence tests developed by Philips and Sul (2007), which is capable of detecting group convergence as well as the presence of club formation in the event of no convergence within the whole sample.

In contrast to previous studies, we find evidence of much stronger regional integration than global integration in the Asian financial markets. In particular, although there are both regional and global convergence in Asian money market before 2008 crisis (with the latter being stronger), regional convergence persists in the post-crisis period while global convergence is no longer observed. For the Asian bond market, although global convergence seems to be stronger prior to the new ABMI Roadmap in May 2008, regional convergence has reversed to become much stronger after, especially when using bond yields with two-year maturity. It shows that these two events in 2008 have reversed Asian financial market's integration from a global market to become a more regional one.

Furthermore, the strongest evidence of convergence is found in the case of the two-year bond market in the case of regional integration after 2008. It confirms our expectation that regional convergence would be relatively stronger in financial markets where interest rates are of longer maturity as these rates are more prone to be influenced by economic fundamentals. The composition of the sub-clubs is also revealing as it suggests that geographical proximity (as is the case for Indonesia and Philippines) as well as the degree of financial openness and depth (as is the case for Singapore, Japan and Hong Kong) may be determining factors. In addition to the Philips and Sul (2007) tests, as a robustness check, we also employ the beta convergence tests. Although the latter provides broadly consistent results in terms of 
convergence for the whole sample, a comparison between the two methods highlights several advantages of the Philips and Sul (2007) methods.

Our study has important policy implications related to further financial integration in southeast Asian countries. First, our empirical results find an abrupt stop in the process of global convergence and persistent (albeit weak) regional convergence in the post-crisis period in Asian money markets. It seems to confirm that given the uncertainty and volatility unleashed by the global financial crisis, the Asian countries have turned to greater regional cooperation and integration (Asian Development Bank, 2013). However, we are rather concerned with the underlying factors that have contributed to this phenomenon, although it is encouraging to observe continuous regional convergence. Such regional convergence could be due to the domestic nature of their money markets and the substantial build-up of savings in the banking systems rather than deeper and broader financial cooperation and higher capital mobility. At the same time, the de-coupling between Asian and US money market rates could be a mere temporary reflection of the different funding sources of these two markets, short-term domestic household savings for the former and long-term international capital markets and debt issuance for the latter, and that the two funding sources behave differently in crisis time. Hence, in the quest for deeper regional financial integration in Asia, challenges persist and these may amplify when the impact of the global crisis wanes.

Second, we observe strong regional integration in the Asian bond markets following the new ABMI Roadmap in May 2008. In fact, over the period 2008-2009, government bonds for 9 Asian countries ${ }^{13}$ increased by $11.2 \%$ to $\$ 3.1$ trillion (Shimuzu, 2010). More broadly, local currency government bond outstanding in the ASEAN+3 counties has maintained a continuously increasing trend during the whole period of 1998-2012 (Asian Development Bank, 2012). In contrast to the large issuance of government bond, the level of financial

\footnotetext{
${ }^{13}$ China, Hong Kong, Indonesia, S.Korea, Malaysia, Philippines, Singapore, Thailand and Vietnam.
} 
system development is still far from high, which may form a constraint to the growth of bond markets. As pointed out by Lee and Park (2009), many Asian countries have lagged behind in the development of bond markets. Therefore, the need for Asian markets to further develop their domestic financial and capital markets is particularly strong and urgent, especially in the context of an integrating bond market, as identified in our study.

To foster further financial integration in Asia, regional cooperation will play an important role. We find that the Asian countries are displaying varying levels of convergence and are even divergent at times. These challenges will have to be addressed in order to ensure deeper financial integration in Asia. 


\section{References}

Acharya, V., Merrouche O., 2010. "Precautionary hoarding of liquidity and interbank markets: Evidence from the sub-prime crisis”. London Business School Working Paper.

Allen, F., Carletti E. and Gale D., 2009. "Interbank Market Liquidity and Central Bank Intervention”. Journal of Monetary Economics, 56(5), 639-652.

Anoruo, E., Ramchander, S. and Thiewes, H. F., 2002. "International linkage of interest rates: Evidence from the emerging economies of Asia”. Global Finance Journal, 13(2), 217-235.

Antzoulatos A., Panopoulou E. and Tsoumas C., 2011. "The enigma of noninterest income convergence”. Applied Financial Economics, 21(17), 1309-1316.

Asian Development Bank, 2012. ASEAN+3 Bond Market Guide.

Asian Development Bank, 2013. "Regional Cooperation and Integration", in Asian Development Bank (ed.), Asian Economic Integration Monitor, October 2013, Asian Development Bank.

Baharumshaha A. Z., Hawa, C. T. and Fountasc, S., 2005. “A panel study on real interest rate parity in East Asian countries: Pre- and post-liberalization era”. Global Finance Journal, 16, 69-85.

Baele L., Fernando A., Hordahl P., Krylova E. and Monnet C., 2004. "Measuring financial integration in the Euro area”. ECB Occasional Paper Series No. 14.

Baltzer M., Cappiello L., De Santis R. A. and Manganelli S., 2008. "Measuring financial integration in new EU member states”. ECB Occasional Paper Series No. 81.

Bank for International Settlements, 2008. "International banking and financial market developments”. Bank for International Settlements Quarterly Review (March 2008).

Barro R. J. and Sala-i-Martin, X., 1991. “Convergence across states and regions”. Yale Economic Growth Center, paper No. 629.

Barro R. J. and Sala-i-Martin, X., 1992. “Convergence”. Journal of Political Economy 100(2): 223251.

Bayoumi, T., 1997. Financial integration and real activity. Manchester University Press.

Bekaert, G., Harvey, C., Lundblad, C. and Siegel, S., 2011. "What segment equitymarkets?” Review of Financial Studies, 24(12), 3841-3890.

Bernard, A.B., Durlauf, S.N., 1996. „Interpreting tests of the convergence hypothesis”. Journal of Econometrics 71,161-173.

Calvi, R. 2010. “Assessing financial integration: a comparison between Europe and East Asia”. European Economy Economic Papers 423, Brussels. 
Caporale G. M., Erdogan B. and Kuzin V., 2009. "Testing for convergence in stock markets: A non-linear factor approach”. CESifo Working Paper Series, No. 2845.

Casu B., and Girardone, C., 2010. "Integration and efficiency convergence in EU banking markets”. Omega 38, 260-267.

Cavoli, T., Rajanb, R. S. and Siregarc, R., 2006. "Financial integration in East Asia: How far? How much further to go?” eSocialSciences Working Papers 372.

Cheung Y-W, Chinn, M. D. and Fujii, E., 2005. "Dimensions of financial integration in Greater China: money markets, banks and policy effects". International Journal of Finance and Economics, 10(2), 117-132.

Donadelli, M., 2013. "Global integration and emerging stock market excess returns". Macroeconomics and Finance in Emerging Market Economies, 6 (2), 244-279.

Donadelli, M. and Paradiso, M., 2014. "Is there heterogeneity in financial integration dynamics? Evidence from country and industry emerging market equity indexes". Journal of International Financial Markets, Institutions and Money, 32, 184-218.

de Browuer, G., 1999. Financial Integration in East Asia. Cambridge University Press.

Eichengreen, B. and Park, Y. C. 2004. "Why has there been less financial integration in Asia than in Europe?” Monetary Authority of Singapore (MAS) Staff Paper.

Eichengreen, B. and Razo-Garcia, R., 2011. "How reliable are De Facto exchange rate regime classifications?” NBER Working Papers 17318, National Bureau of Economic Research.

European Central Bank, 2013. "Financial integration in Europe”, European Central Bank, Eurosystem. April.

Feldstein, M. and Horioka C., 1980. “Domestic saving and international capital flows”. Economic Journal 90, 314-29

Fischer C., 2009. "Price convergence in the EMU? Evidence from micro data". Deutsche Bundesbank, Research Centre, Discussion Paper Series 1(6).

Frankel, J., 1991. "Quantifying international capital mobility in the 1980s”. in B. Bernheim and J. Shoven (ed.), National saving and economic performance, Chicago: University of Chicago Press.

Fung L., K-P, Yu, I-W. and Tam C-S, 2008. “Assessing the integration of Asian's equity and bond markets", in: Bank for International Settlements (ed.), Regional financial integration in Asia: present and future, 42, 1-37, Bank for International Settlements.

Higson C., Holly S. and Petralla I., 2009. "The financial integration of the European Union: common and idiosyncratic drivers". Working paper D.1.1d, European Commission, $7^{\text {th }}$ Framework Programme. 
Hodrick, R. and Prescott, E. C., 1997. "Postwar U.S. business cycles: An empirical investigation”. Journal of Money, Credit, and Banking 29 (1), 1-16.

Holmes M. J., Otero, J. and Panagiotidis, T., 2011."Real interest parity: A note on Asian countries using panel stationarity tests," Journal of Asian Economics, 22, 550-557.

Grilli, V. and Milesi-Ferretti G.M, 1995. "Economic effects and structural determinants of capital controls”. IMF Staff Papers 42, 517-51.

Ibrahim, S., 2009. "East Asian financial integration: A cointegration test allowing for structural break and the role of regional institutions". International Journal of Economics and Management 3(1),184-203.

Islam N., 2003. "What have we learnt from the convergence debate?”. Journal of Economic Surveys, 17(3), 309-362, 07.

Kearney, C. and Lucey, B. M., 2004. "Equity market integration: Theory, evidence and implications”. International Review of Financial Analysis, 13(5), 571-83.

Kim, S., Lee, J-W. and Shin K., 2006. "Regional and global financial integration in east Asia”. Korea University Discussion Paper Series 0602. Seoul.

Kim, S. and Lee J-W., 2012. "Real and financial integration, real and financial integration in east Asia”. Review of International Economics, 20(2), 332-349.

Lee, C. S. and Park, C.-Y., 2009. "Beyond the crisis: Financial regulatory reform in emerging Asia”. ADB Working Paper Series on Regional Economic Integration.34.

Magud, N. and Reinhart C., 2006. “Capital controls: An evaluation”. NBER Working Paper 11973.

Park C.-Y. and Lee, J.-W., 2011. "Financial integration in emerging Asia: Challenges and prospects”. Asian Economic Policy Review, 6, 176-198.

Phillips P. C. B., and Sul D., 2007. “Transition modelling and econometric convergence tests”. Econometrica 75, 1771-1855.

Phillips P. C. B. and Sul D., 2009. "Economic transition and growth". Journal of Applied Econometrics. 24, 1153-1185.

Poonpatpibul, C. S. Tanboon and P. Leelapornchai. 2006. "The role of financial integration in east Asia in promoting regional growth and stability”. Bank of Thailand. Mimeo.

Pukthuanthong, K. and Roll, R., 2009. "Global market integration: An alternative measure and its application”, Journal of Financial Economics, 92(2), 214-232.

Rughoo, A. and Sarantis, N., 2012. "Integration in European retail banking: Evidence from savings and lending rates to non-financial corporations”. Journal of International Financial Markets, Institutions and Money 22(5), 1307-1327. 
Rughoo, A. and Sarantis, N., 2014. "The global financial crisis and integration in European retail banking”. Journal of Banking and Finance 40, 28-41.

Shimuzu S., 2010. "The development of Asian bond markets since the global financial crisis -significance and challenges”. Pacific Business and Industries 10 (38).

Singh. M. and Banerjee A., 2006. “Testing real interest parity in emerging markets”, IMF Working Paper WP/06/249.

Sul, D., 2007. Gauss codes for the computation of the panel convergence logt test and convergence clubs, proposed in Phillips and Sul (2007).

Tang, K-B, 2011, “The precise form of uncovered interest parity: A heterogeneous panel application in ASEAN-5 countries”, Economic Modelling, 28(1-2), 568-573.

Qin, D., 2007. "Measuring regional market integration in developing Asia: A Dynamic Factor Error Correction Model (DF-ECM) approach”. Working Paper Series on Regional Economic Integration 8.

Vo, X. V., 2009, “International financial integration in Asian bond markets”. Research in International Business and Finance 23, 90-106.

Vajanne L., 2007. "Integration in euro-area retail banking markets -convergence of credit interest rates”. Bank of Finland Research Discussion paper No. 27.

Volosovych, V., 2011. "Measuring financial market integration over the long run: Ist here a U-shape?”. Journal of International Money and Finance, 30, 1535-1561.

Volosovych, V., 2013. "Learning about financial market integration from principal components analysis.” CESifo Economic Studies 59 (2), 360-391.

Weill L., 2009. "Convergence in banking efficiency across European countries”. Journal of International Financial Markets, Institutions and Money 19, 818-833.

You, K. and Sarantis, N., 2011. "Structural breaks and the equilibrium Chinese Yuan/US Dollar real exchange rate: A FEER approach”. Review of International Economics, 19(5), 791-808.

You, K. and N. Sarantis, N., 2012. "A twelve-area model for the equilibrium Chinese Yuan/US Dollar nominal exchange rate”. Journal of International Financial Markets, Institutions and Money, 22(1), 151-170.

You, K. and N. Sarantis, N., 2012. "Structural breaks and the equilibrium real effective exchange rate of China: A NATREX approach”. China Economic Review, 23, 1146-1163. 
Figure 1. Absolute amount of local currency (LCY) bonds outstanding in USD billions in Southeast Asia

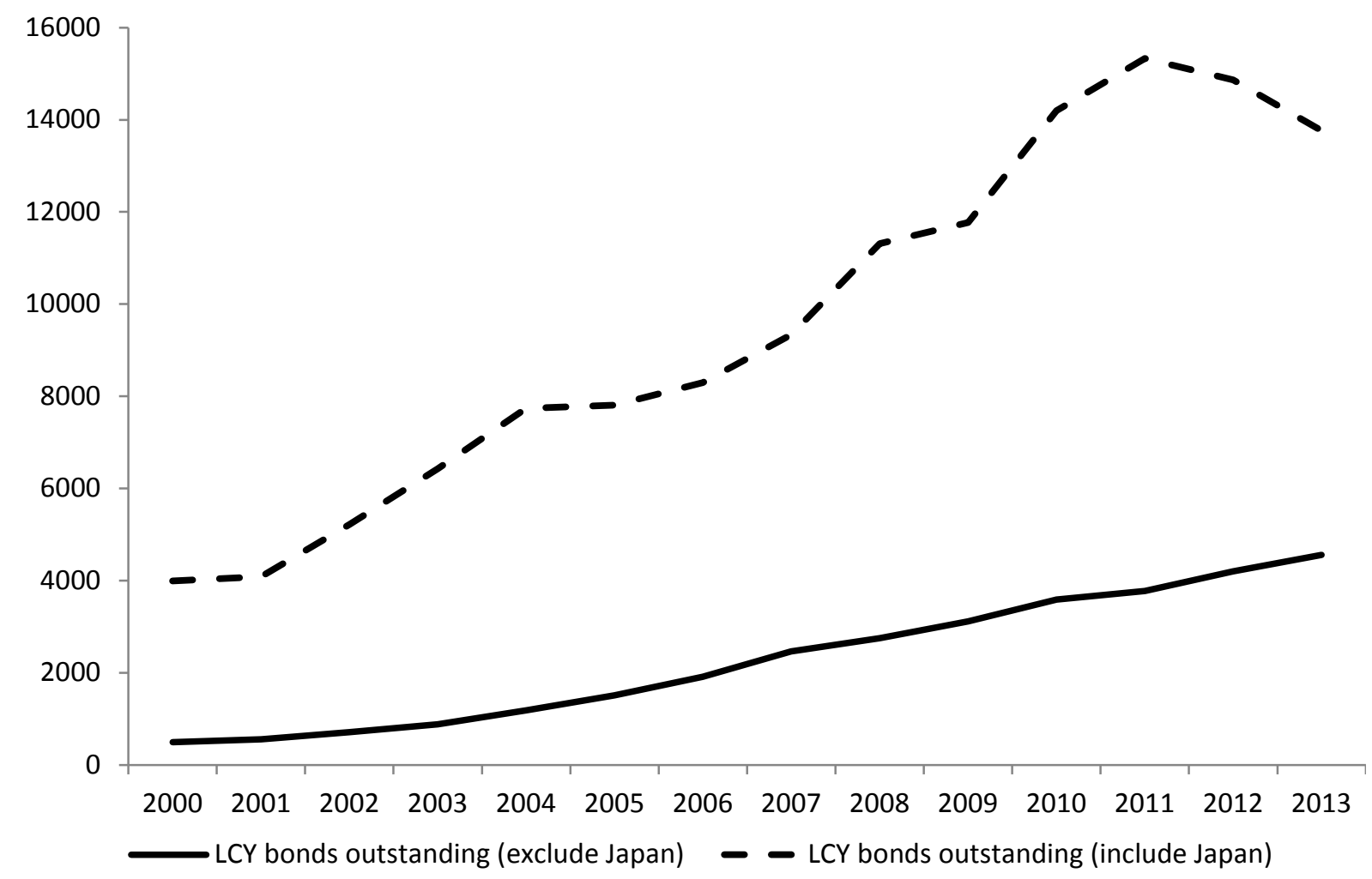

Note: The following countries are included: People's Republic of China, Hongkong (China), Indonesia, Republic of Korea, Malaysia, Philippines, Singapore, Thailand, Vietnam and Japan. Data source: Asian Development Bank. 


\section{Appendix A (Figures 2a-5c)}

Figure 2a. One-month interbank spread against the US rate

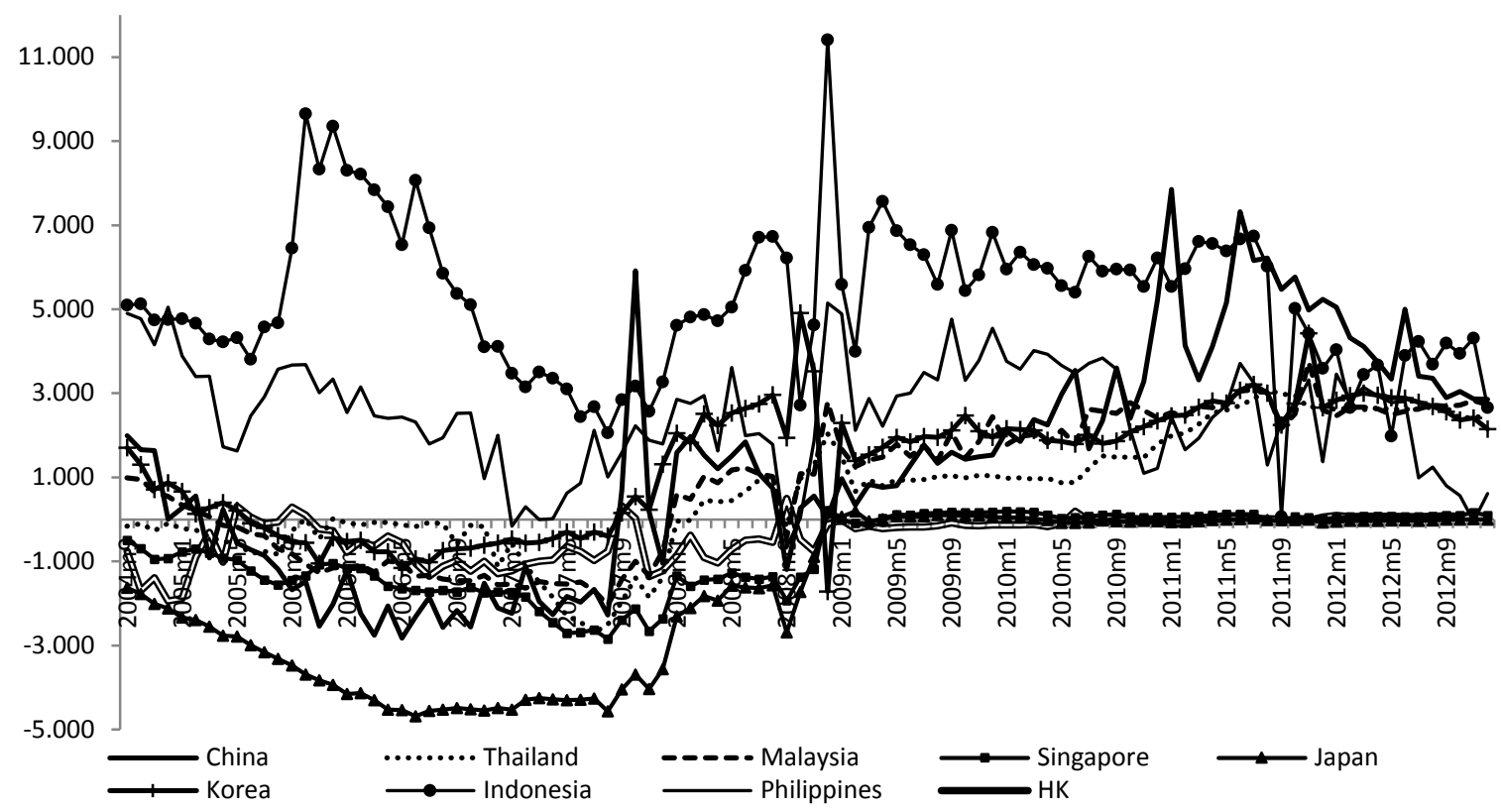

Figure 2b. One-month interbank spread against the Japan rate

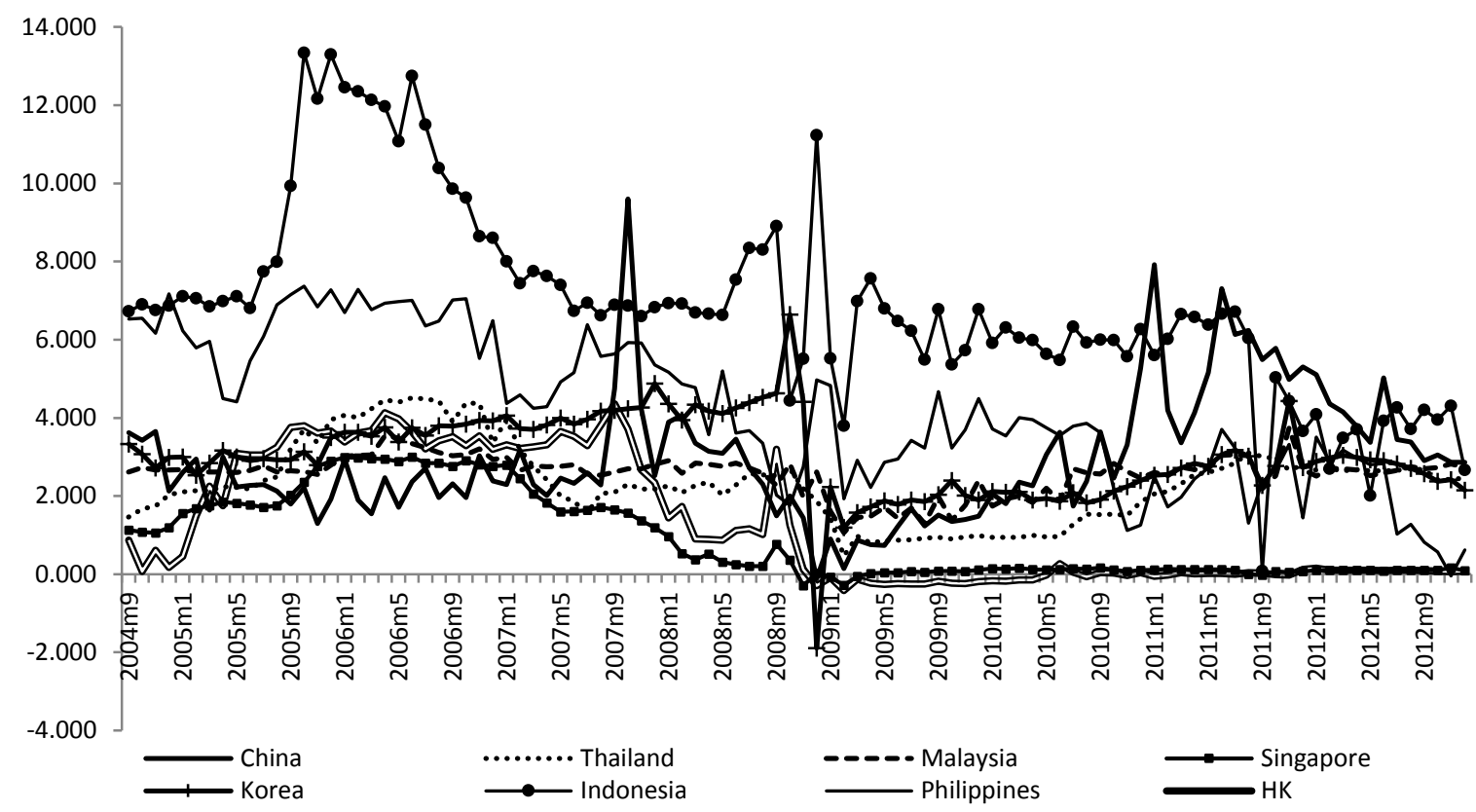

Figure 2c. One-month interbank spread against the weighted average 


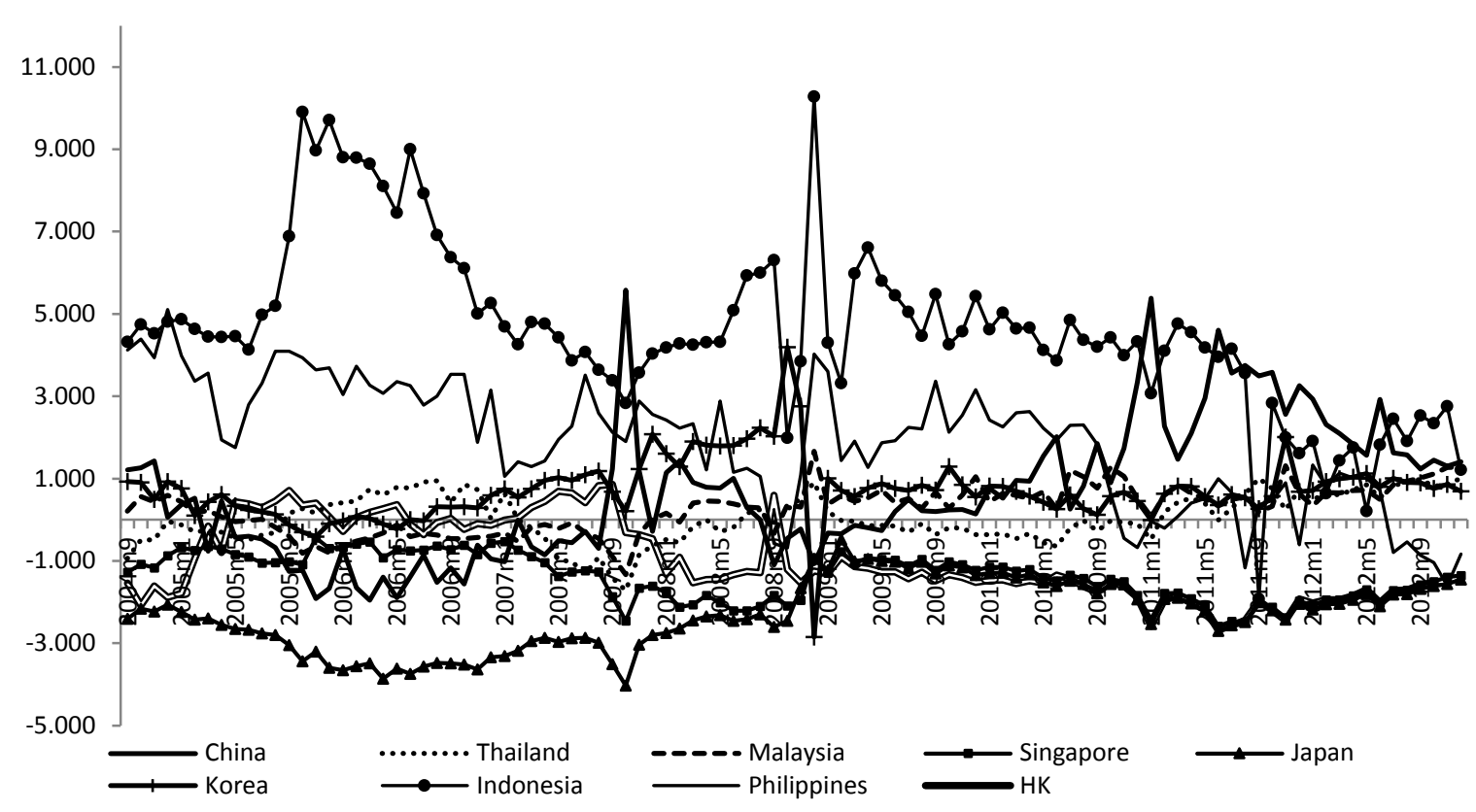

Figure 3a. Three-month interbank spread against the US rate

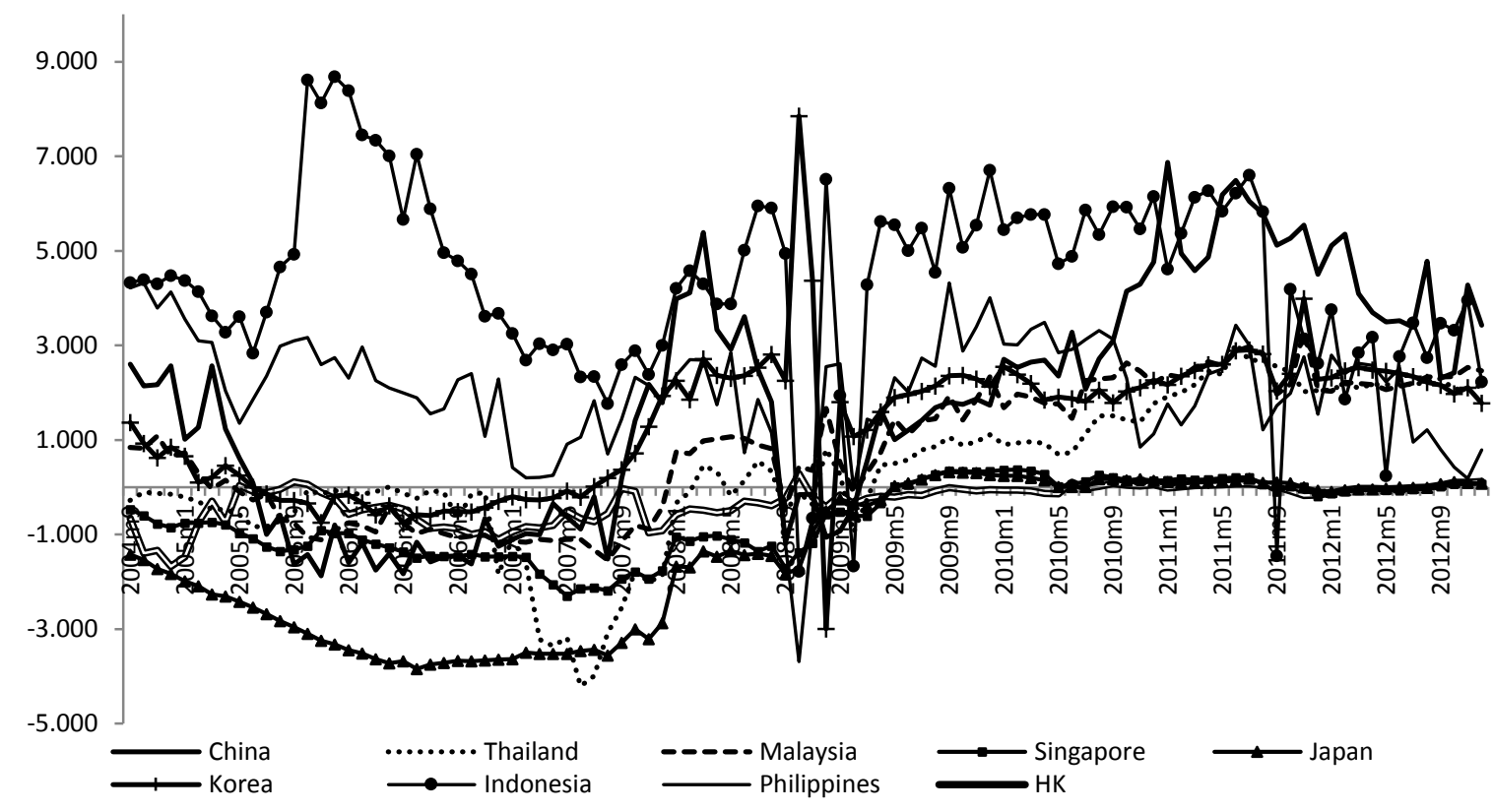

Figure 3b. Three-month interbank spread against the Japan rate 


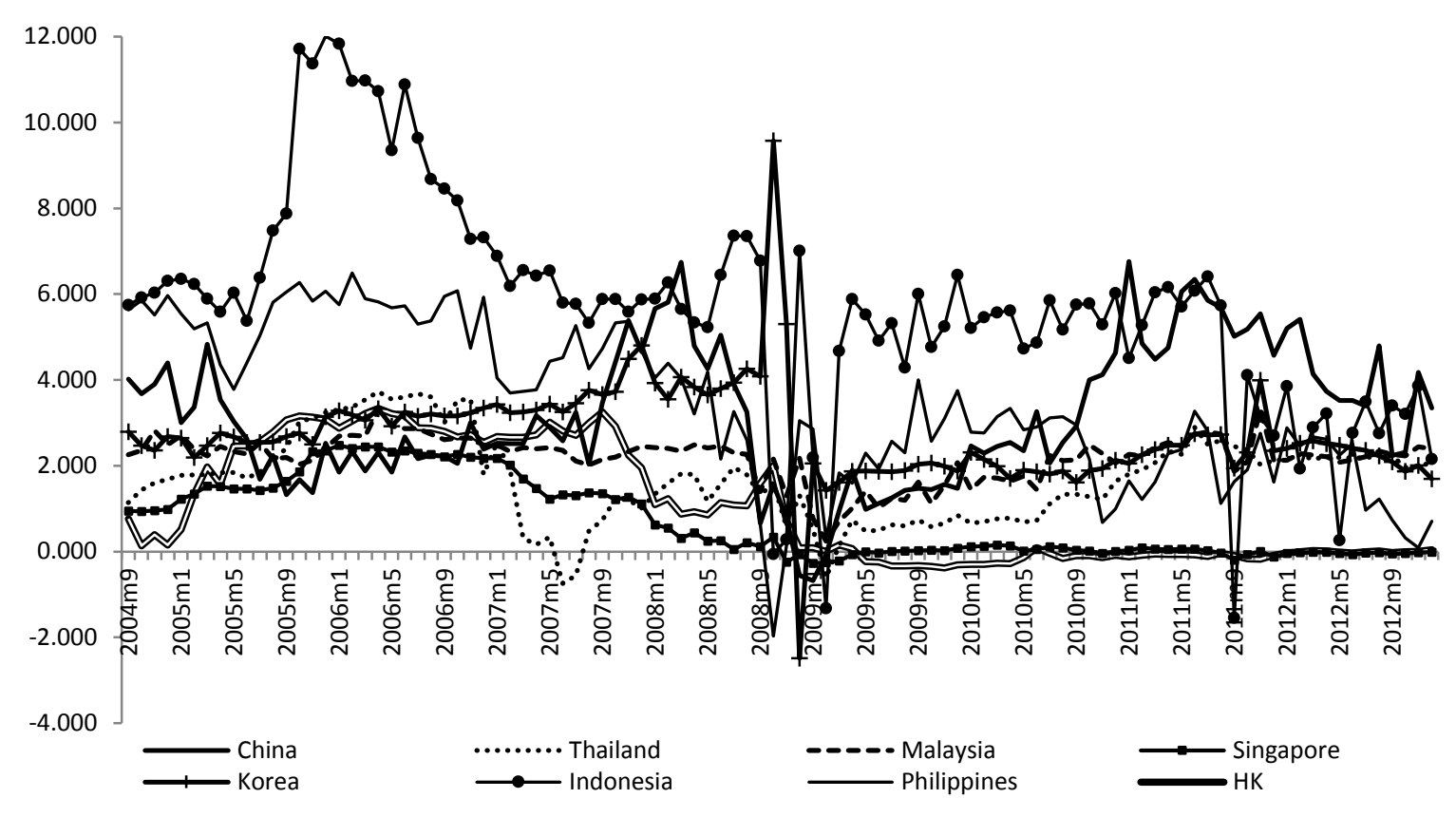

Figure 3c. Three-month interbank spread against the weighted average

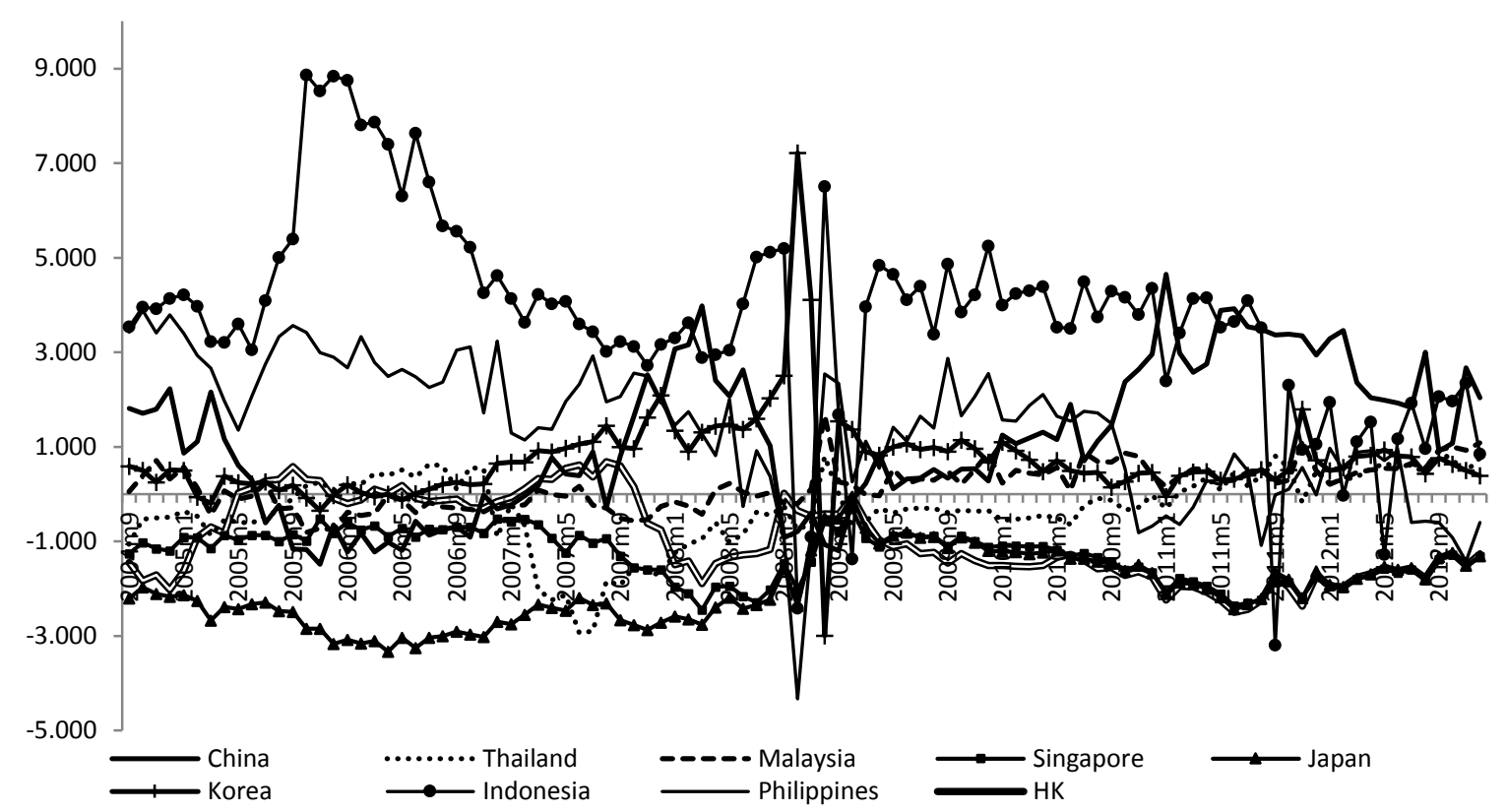

Figure 4a. One-year government bond spread against the US rate 


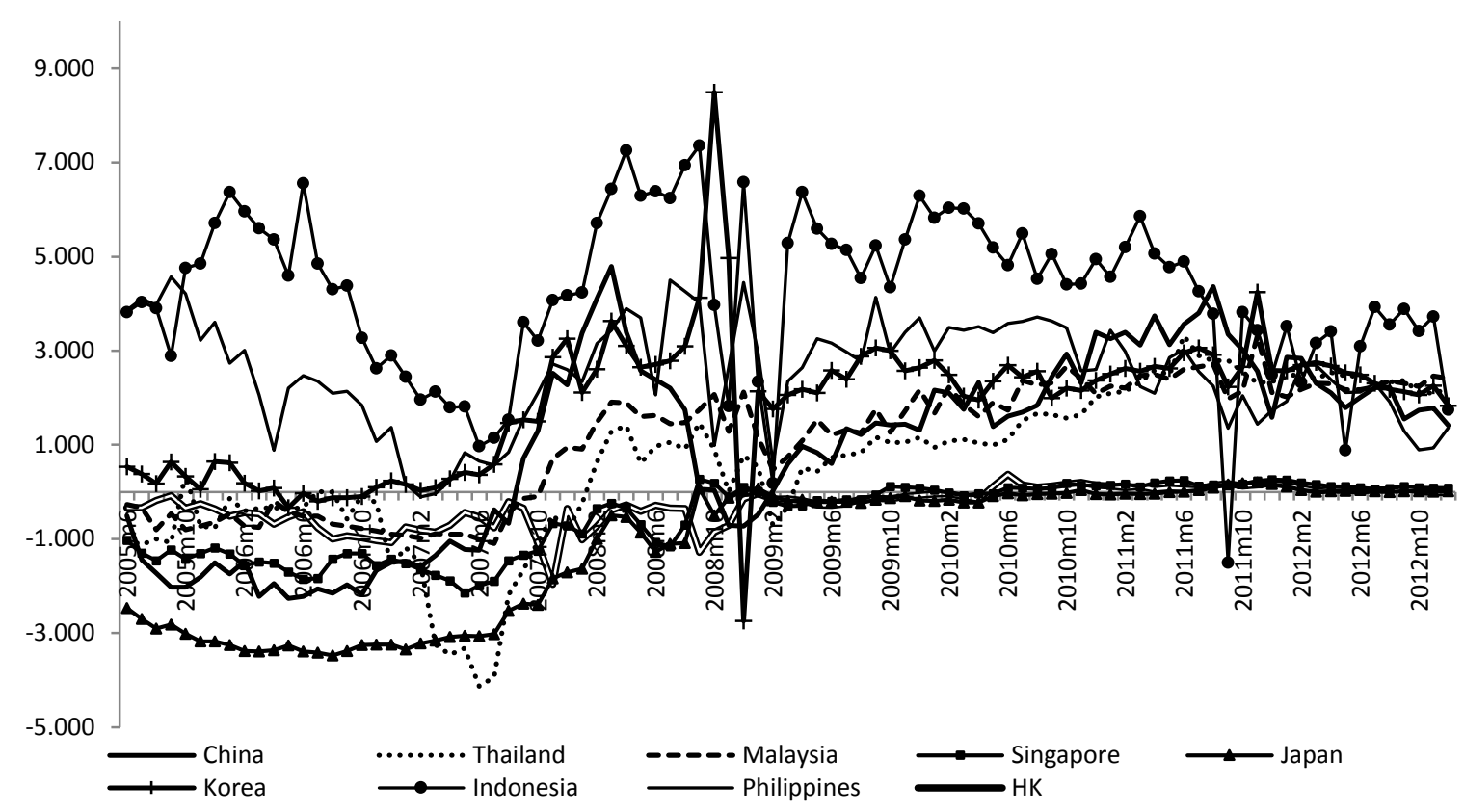

Figure 4b. One-year government bond spread against the Japan rate

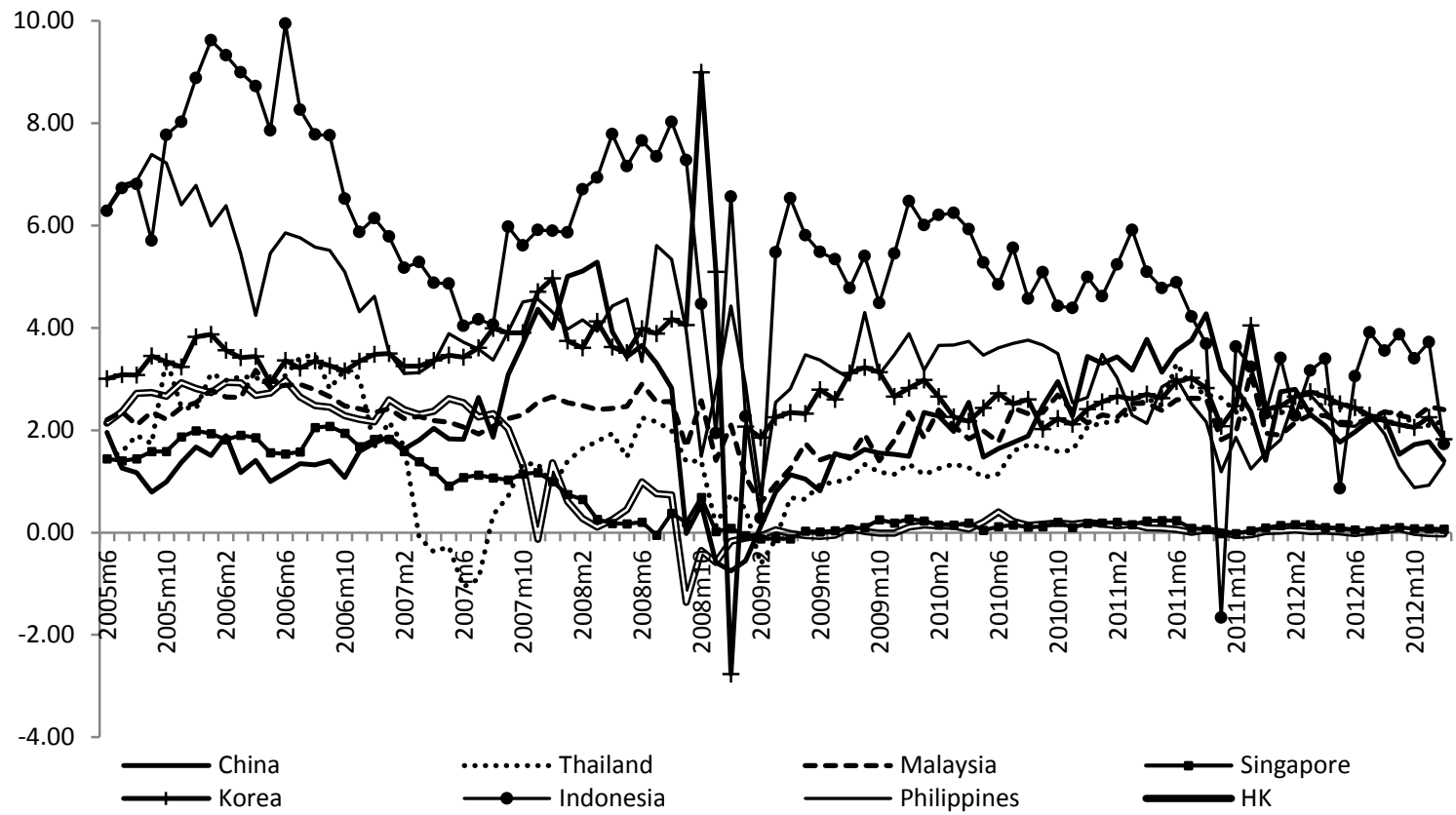


Figure 4c. One-year government bond spread against the weighted average

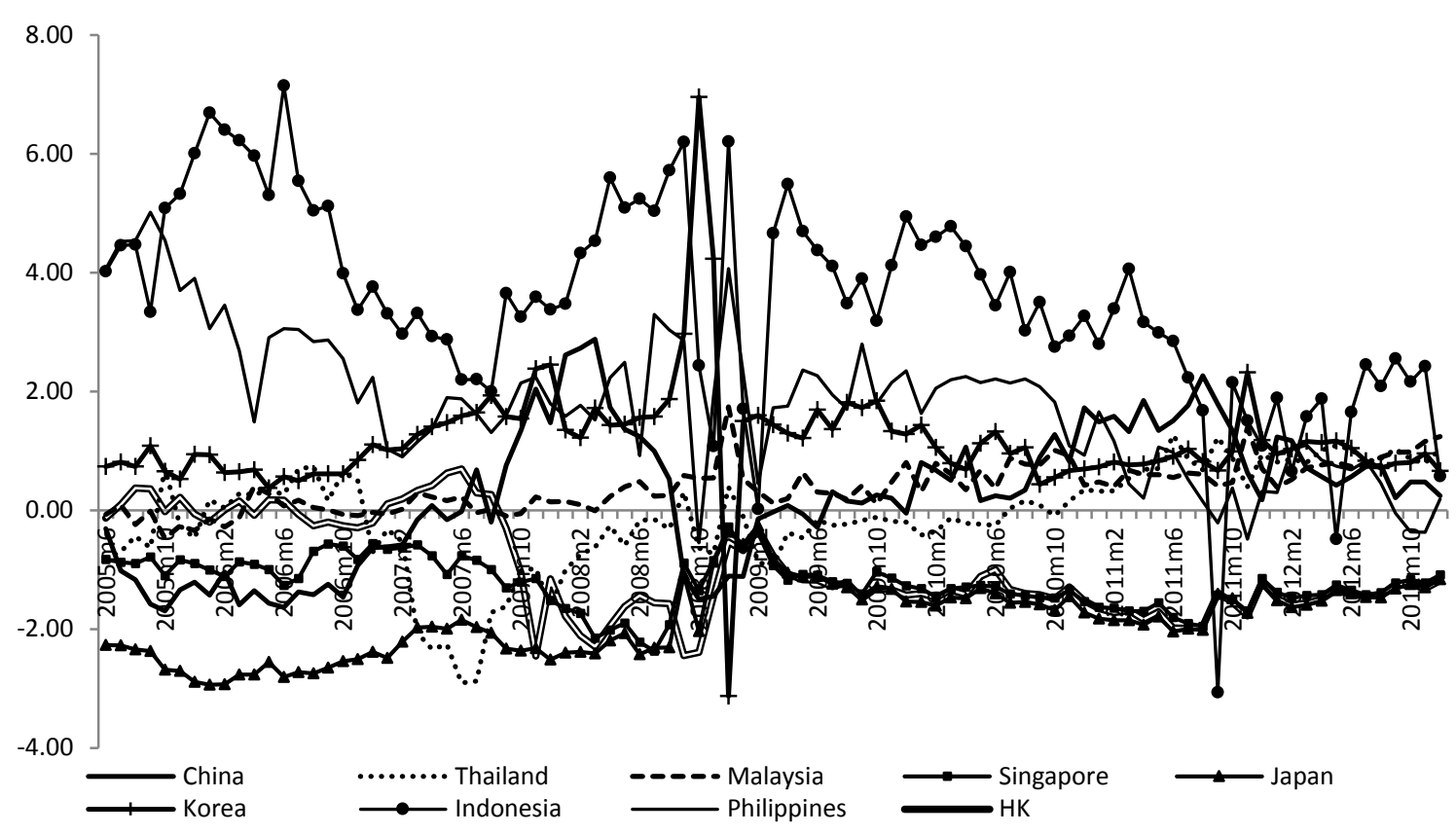

Figure 5a. Two-year government bond spread against the US rate

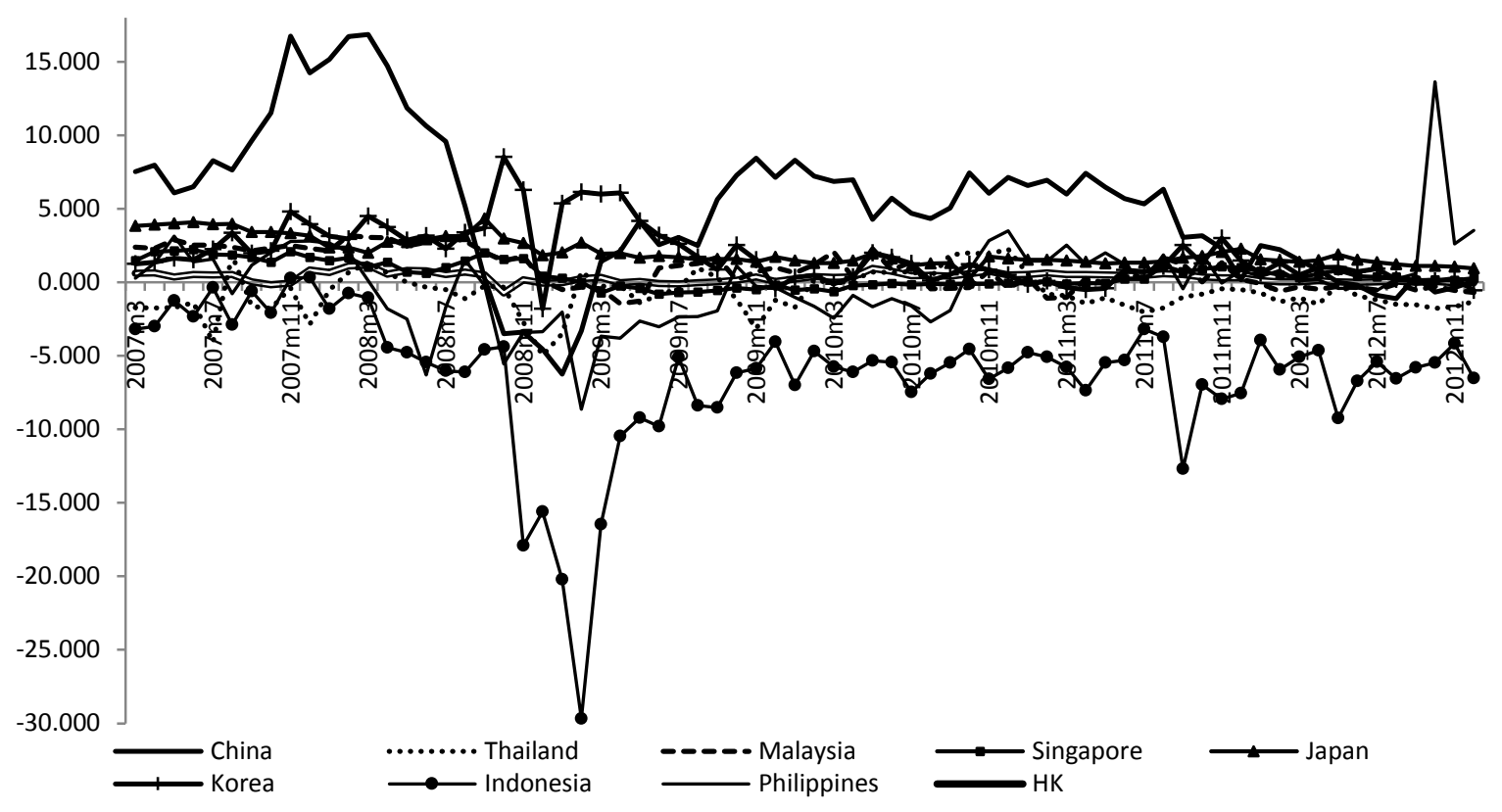


Figure 5b. Two-year government bond spread against the Japan rate

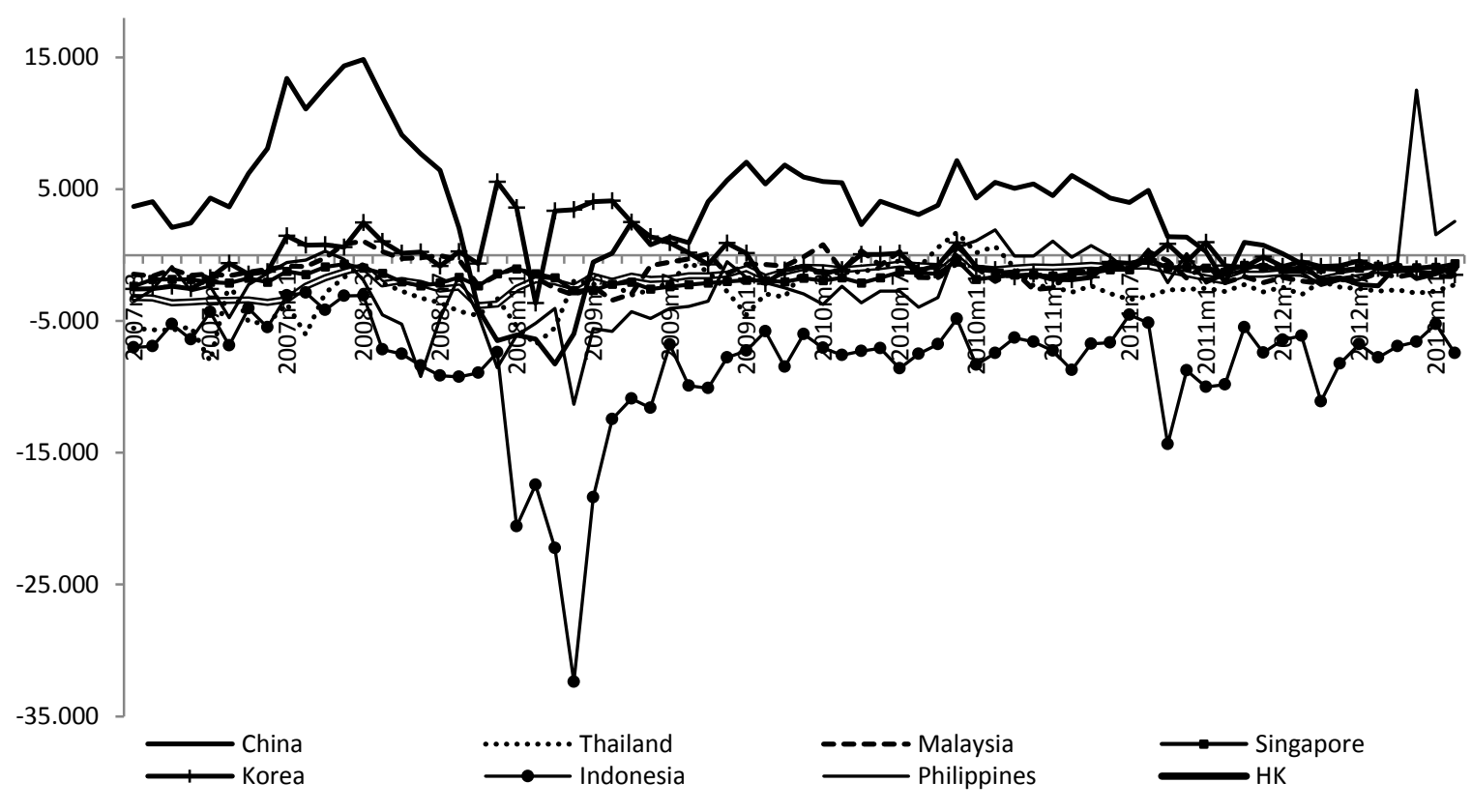

Figure 5c. Two-year government bond spread against the weighted average

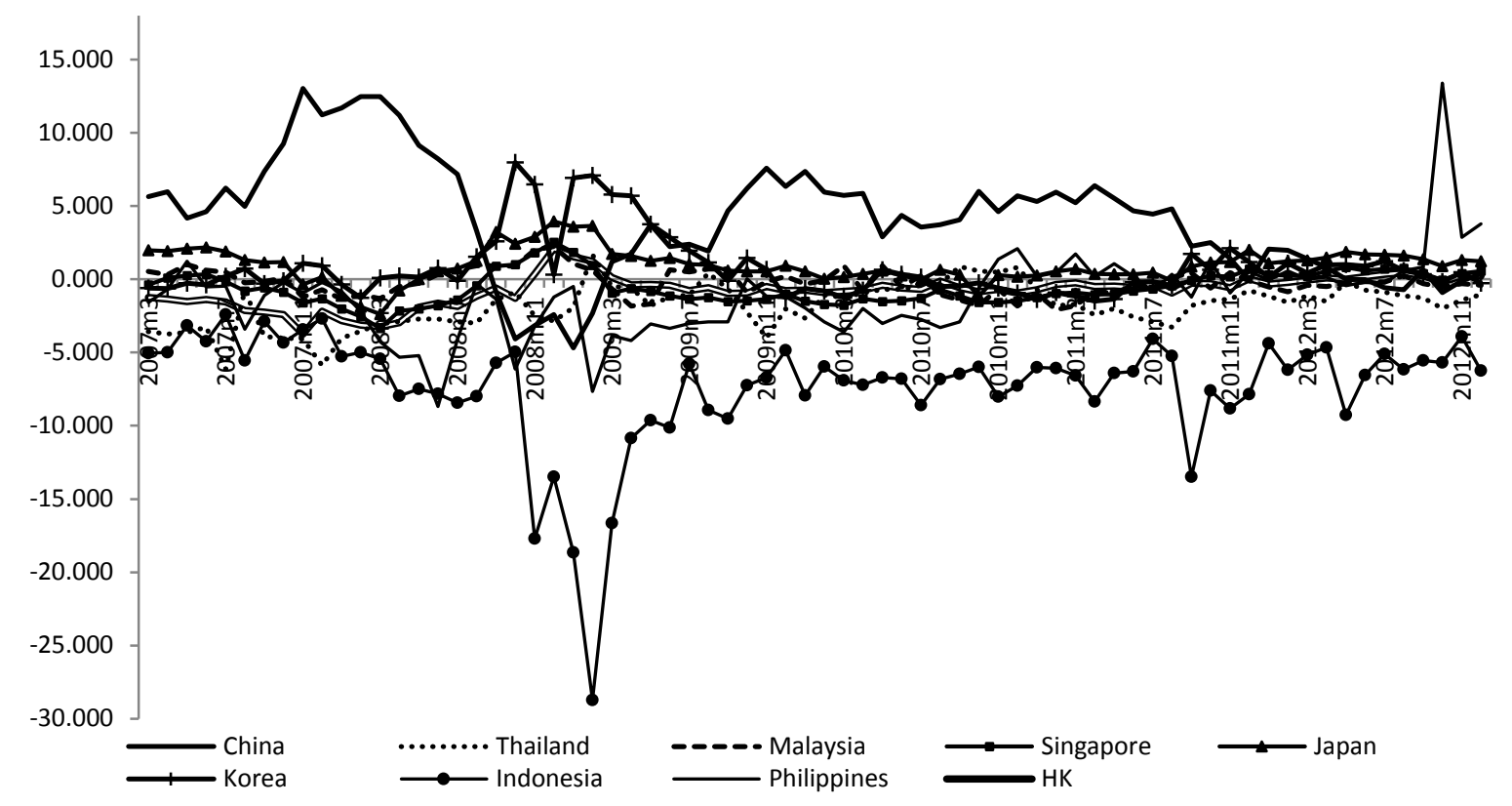


Figure 6a. Transition paths for 1-month interbank spreads

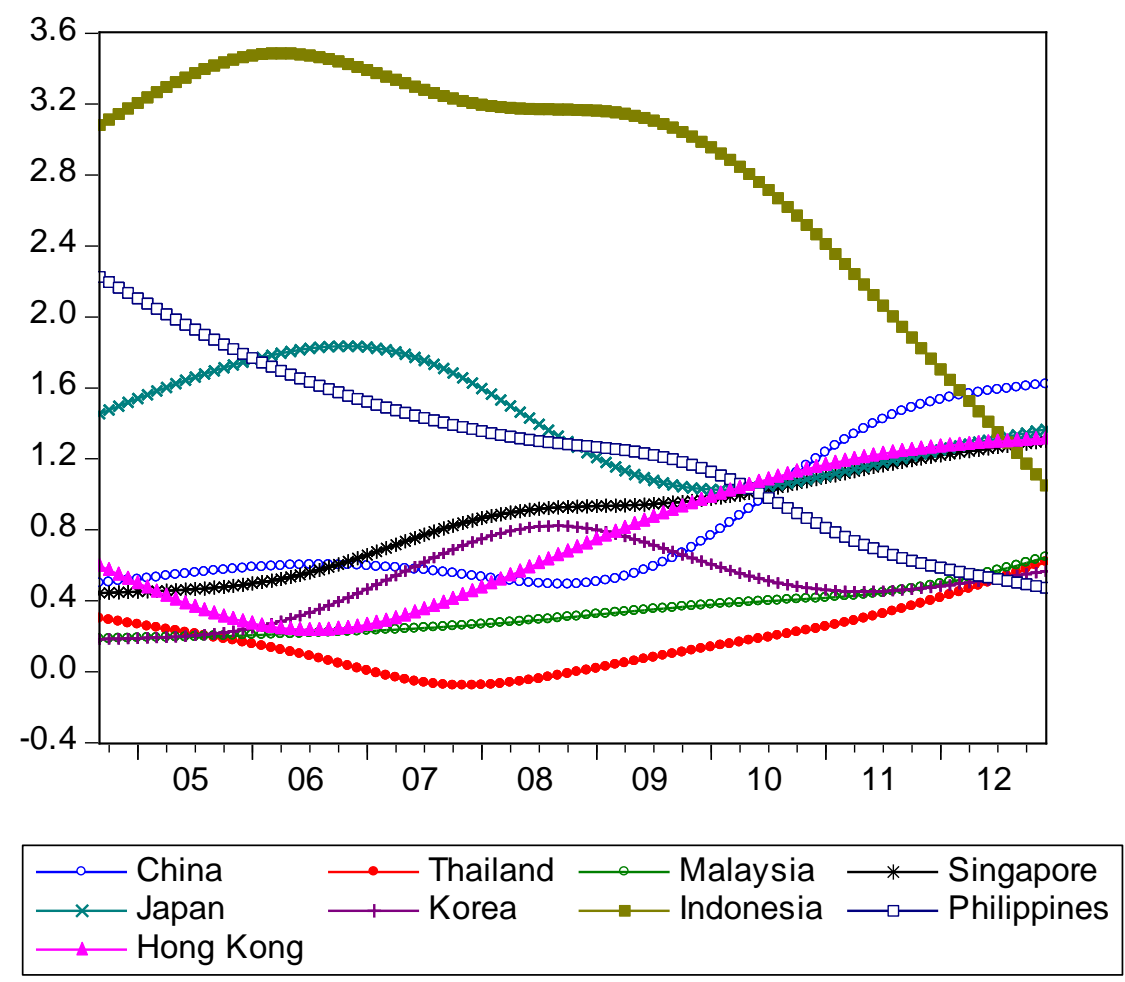

Figure6b. Transition paths for 3-months interbank spreads

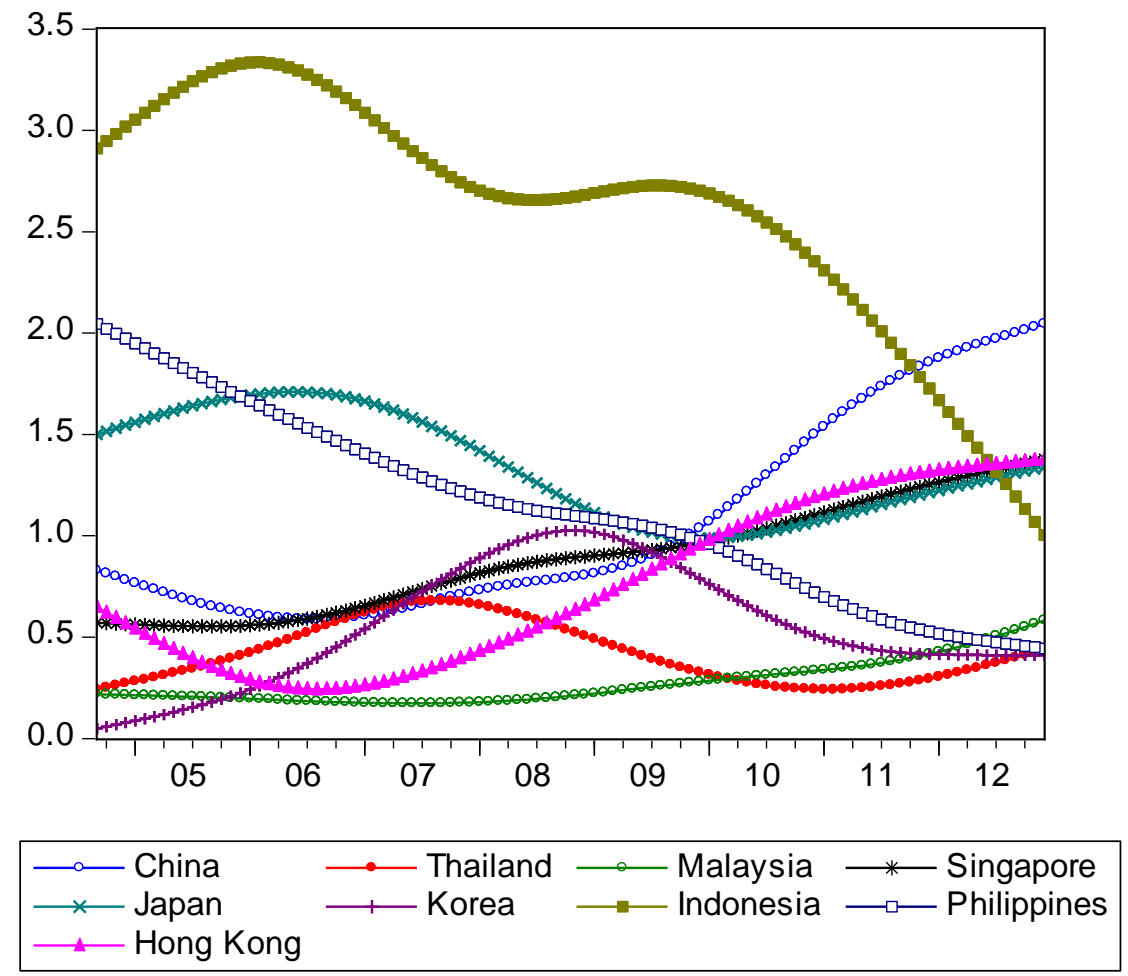


Figure $6 \mathrm{c}$. Transition paths for 1-year bond spreads

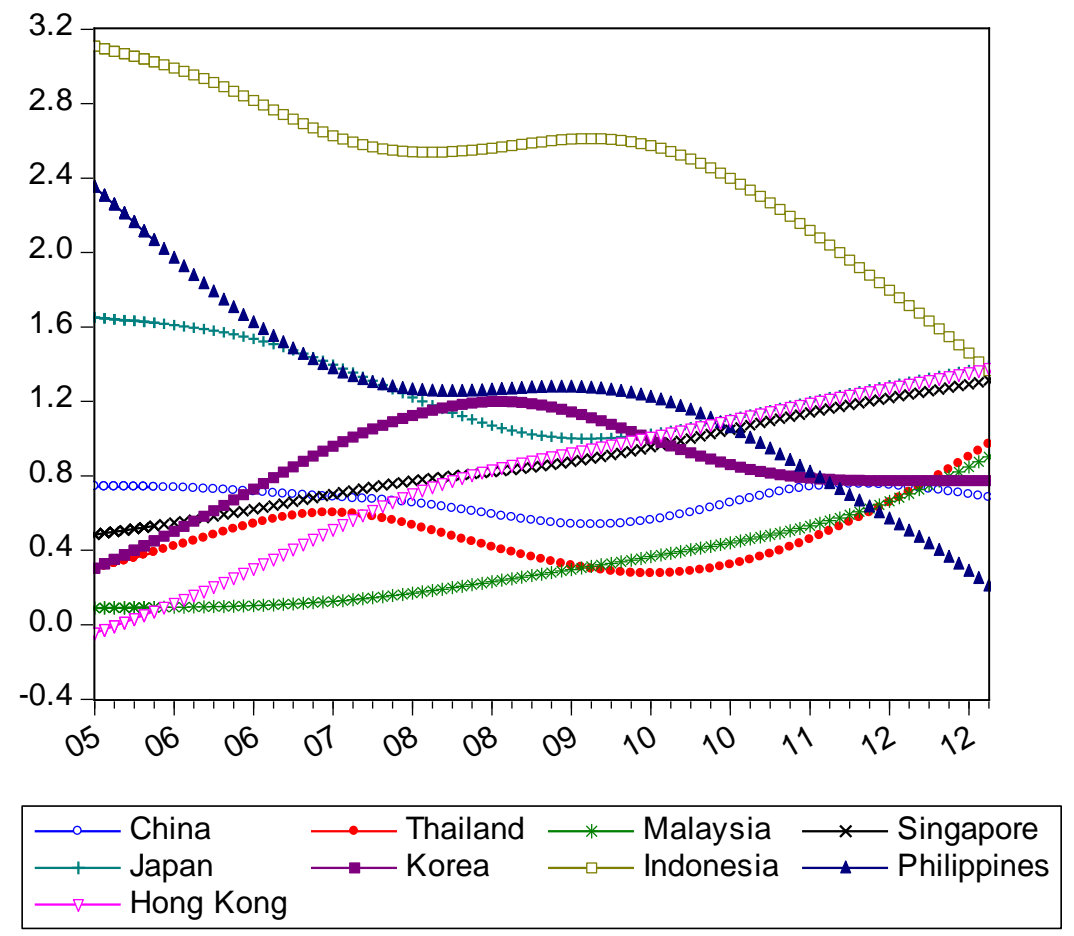

Figure $6 \mathrm{~d}$. Transition paths for 2-year bond spreads

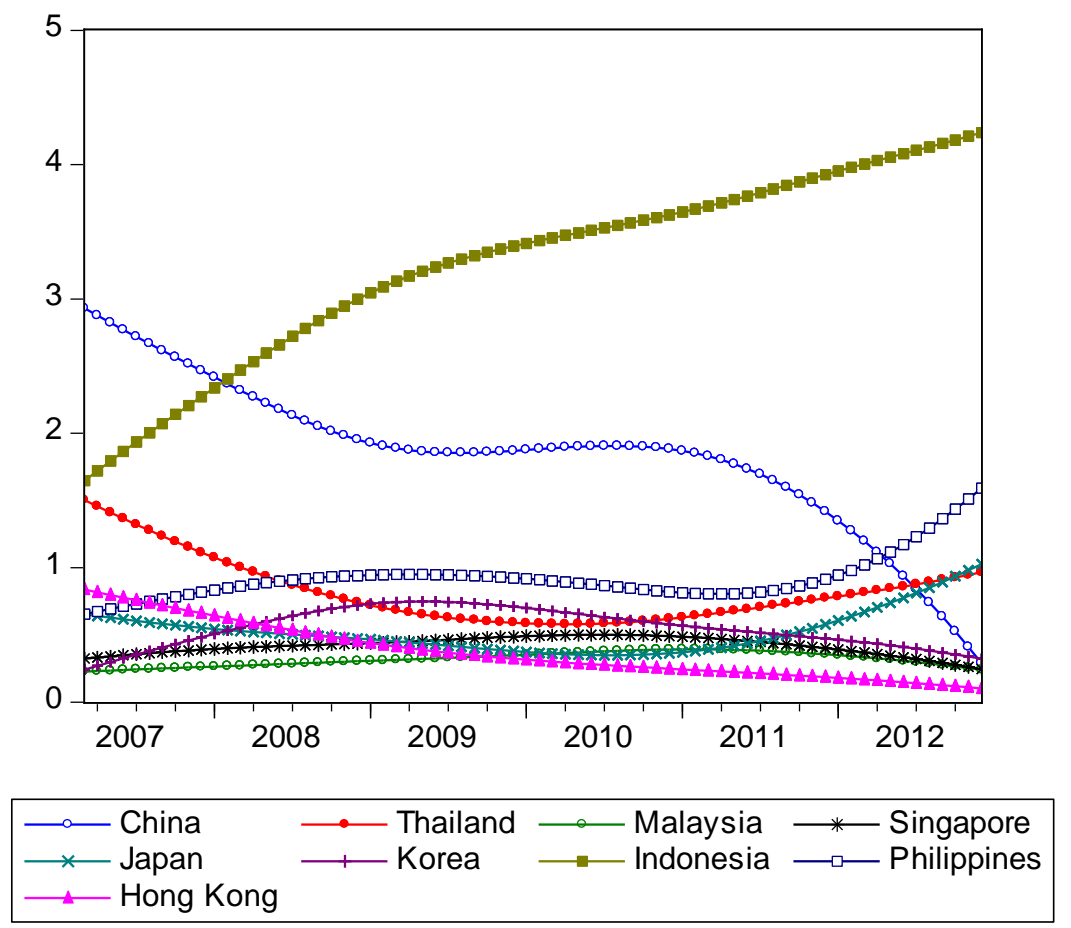


Appendix B (Table 1a-1d)

Table 1a: Descriptive statistics for 1-month interbank spreads against the weighted average

\begin{tabular}{|c|c|c|c|c|c|c|c|c|c|}
\hline & $\mathrm{CH}$ & $\mathrm{TH}$ & MAL & SIN & JP & $\mathrm{KO}$ & INDO & $\mathrm{PH}$ & HK \\
\hline Mean & 0.65 & 0.04 & 0.27 & -1.38 & -2.30 & 0.73 & 4.60 & 1.89 & -1.01 \\
\hline Median & 0.41 & -0.02 & 0.35 & -1.27 & -2.31 & 0.70 & 4.44 & 2.04 & -1.33 \\
\hline Max & 5.58 & 1.00 & 1.66 & -0.44 & -0.48 & 4.19 & 10.28 & 5.10 & 0.86 \\
\hline Min & -1.95 & -1.72 & -1.33 & -2.59 & -4.03 & -2.84 & -1.92 & -1.60 & -2.68 \\
\hline Std. Dev. & 1.61 & 0.59 & 0.57 & 0.56 & 0.83 & 0.77 & 2.09 & 1.50 & 0.95 \\
\hline Skewness & 0.75 & -0.33 & -0.18 & -0.29 & -0.09 & 0.29 & 0.34 & -0.32 & 0.43 \\
\hline Kurtosis & 3.40 & 2.85 & 2.79 & 2.00 & 2.15 & 10.43 & 4.16 & 2.37 & 1.97 \\
\hline Jarque-Bera & 10.09 & 1.92 & 0.73 & 5.63 & 3.16 & 231.74 & 7.59 & 3.37 & 7.49 \\
\hline Probability & 0.01 & 0.38 & 0.69 & 0.06 & 0.21 & 0.00 & 0.02 & 0.19 & 0.02 \\
\hline Sum & 64.92 & 4.46 & 26.62 & -137.8 & -230.4 & 73.31 & 460.33 & 189.17 & -100.66 \\
\hline Sum Sq. Dev. & 257.75 & 34.18 & 31.64 & 30.90 & 67.60 & 58.23 & 431.76 & 223.08 & 88.42 \\
\hline
\end{tabular}

Table 1b.Descriptive statistics for 3-months interbank spreads against the weighted average

\begin{tabular}{|c|c|c|c|c|c|c|c|c|c|}
\hline & $\mathrm{CH}$ & $\mathrm{TH}$ & MAL & SIN & JP & KO & INDO & $\mathrm{PH}$ & HK \\
\hline Mean & 1.14 & -0.31 & 0.17 & -1.30 & -2.01 & 0.74 & 3.73 & 1.42 & -0.96 \\
\hline Median & 1.07 & -0.30 & 0.20 & -1.17 & -2.17 & 0.58 & 3.94 & 1.56 & -1.26 \\
\hline Max & 4.65 & 0.90 & 1.67 & -0.31 & -0.05 & 7.22 & 8.87 & 3.89 & 0.69 \\
\hline Min & -1.48 & -2.94 & -0.81 & -2.45 & -3.33 & -2.99 & -3.19 & -4.33 & -2.50 \\
\hline Std. Dev. & 1.52 & 0.79 & 0.46 & 0.52 & 0.73 & 0.98 & 2.17 & 1.44 & 0.87 \\
\hline Skewness & 0.15 & -1.09 & 0.28 & -0.39 & 0.29 & 2.86 & -0.29 & -0.77 & 0.28 \\
\hline Kurtosis & 2.04 & 4.42 & 3.06 & 2.07 & 2.35 & 23.32 & 4.53 & 4.15 & 1.81 \\
\hline Jarque-Bera & 4.22 & 28.14 & 1.33 & 6.14 & 3.18 & 1855.86 & 11.10 & 15.36 & 7.21 \\
\hline Probability & 0.12 & 0.00 & 0.52 & 0.05 & 0.20 & 0.00 & 0.00 & 0.00 & 0.03 \\
\hline Sum & 113.93 & -30.8 & 17.24 & -129.6 & -201.0 & 73.54 & 373.35 & 141.52 & -96.01 \\
\hline Sum Sq. Dev. & 229.85 & 61.68 & 21.02 & 26.96 & 52.24 & 95.30 & 467.28 & 204.13 & 74.89 \\
\hline
\end{tabular}

Table 1c. Descriptive statistics 1-year bond spreads against the weighted average

\begin{tabular}{|c|c|c|c|c|c|c|c|c|c|}
\hline & $\mathrm{CH}$ & $\mathrm{TH}$ & MAL & SIN & JP & KO & INDO & $\mathrm{PH}$ & HK \\
\hline Mean & 0.25 & -0.10 & 0.38 & -1.23 & -1.85 & 1.19 & 3.54 & 1.81 & -0.99 \\
\hline Median & 0.24 & -0.12 & 0.37 & -1.23 & -1.84 & 1.05 & 3.47 & 1.80 & -1.29 \\
\hline Max & 2.88 & 1.27 & 1.74 & -0.28 & -0.26 & 6.96 & 7.15 & 5.02 & 0.70 \\
\hline Min & -1.69 & -2.90 & -0.47 & -2.37 & -2.93 & -3.12 & -3.07 & -0.54 & -2.45 \\
\hline Std. Dev. & 1.14 & 0.89 & 0.40 & 0.42 & 0.60 & 0.96 & 1.72 & 1.22 & 0.81 \\
\hline Skewness & 0.04 & -1.01 & 0.52 & -0.25 & 0.18 & 1.89 & -0.61 & 0.34 & 0.41 \\
\hline Kurtosis & 2.28 & 4.20 & 3.50 & 2.98 & 2.52 & 20.90 & 4.35 & 2.94 & 2.04 \\
\hline Jarque-Bera & 2.01 & 21.00 & 5.10 & 0.97 & 1.37 & 1269.13 & 12.57 & 1.76 & 6.05 \\
\hline Probability & 0.37 & 0.00 & 0.08 & 0.61 & 0.50 & 0.00 & 0.00 & 0.42 & 0.05 \\
\hline Sum & 22.48 & -9.03 & 35.03 & -112.1 & -168.1 & 108.17 & 321.99 & 164.39 & -89.91 \\
\hline Sum Sq. Dev. & 117.96 & 70.74 & 14.61 & 15.56 & 32.76 & 82.39 & 264.84 & 133.25 & 58.97 \\
\hline
\end{tabular}


Table 1d. Descriptive statistics 2-year bond spreads against the weighted average

\begin{tabular}{|c|c|c|c|c|c|c|c|c|c|}
\hline & $\mathrm{CH}$ & $\mathrm{TH}$ & MAL & SIN & JP & $\mathrm{KO}$ & INDO & $\mathrm{PH}$ & HK \\
\hline Mean & 4.03 & -1.82 & -0.21 & -0.58 & 0.96 & 0.79 & -7.34 & -1.18 & -0.76 \\
\hline Median & 4.41 & -1.56 & -0.27 & -0.81 & 0.95 & 0.21 & -6.43 & -0.88 & -0.59 \\
\hline Max & 13.03 & 1.67 & 2.24 & 2.54 & 3.96 & 7.96 & -2.40 & 13.40 & 2.09 \\
\hline Min & -4.68 & -6.14 & -2.08 & -3.37 & -2.38 & -1.50 & -28.73 & -8.68 & -3.75 \\
\hline Std. Dev. & 3.95 & 1.51 & 0.90 & 1.10 & 1.14 & 2.09 & 4.06 & 2.89 & 1.05 \\
\hline Skewness & 0.16 & -0.40 & 0.13 & 0.37 & 0.02 & 1.93 & -2.83 & 1.39 & -0.48 \\
\hline Kurtosis & 2.88 & 3.34 & 2.97 & 3.05 & 4.24 & 6.29 & 13.58 & 11.16 & 4.05 \\
\hline Jarque-Bera & 0.35 & 2.19 & 0.20 & 1.64 & 4.51 & 74.83 & 419.78 & 216.68 & 5.88 \\
\hline Probability & 0.84 & 0.33 & 0.90 & 0.44 & 0.11 & 0.00 & 0.00 & 0.00 & 0.05 \\
\hline Sum & 281.82 & -127.41 & -14.5 & -40.87 & 67.10 & 55.23 & -513.93 & -82.29 & -53.10 \\
\hline Sum Sq. Dev. & 1078.86 & 156.45 & 55.37 & 84.17 & 89.05 & 302.40 & 1137.01 & 576.70 & 76.22 \\
\hline
\end{tabular}

Note: the countries are China (CH), Thailand (TH), Malaysia (MAL), Singapore (SIN), Japan (JP), Korea (KO), Indonesia (INDO), Philippines (PH), Hong-Kong (HK) 
Table 2. Convergence test for the interbank CID against the US's rate

\begin{tabular}{lcc}
\hline \multicolumn{1}{c}{ Data series } & $\hat{b}$ & t-statistics \\
\hline One month interbank spread against US rate & & \\
Pre-crisis Sept 2004 - August 2008 & -0.358 & -0.457 \\
Post-crisis Sept 2008- December 2012 & -0.101 & $-6.781^{*}$ \\
\hline Three month interbank spread against US rate & & \\
Pre-crisis Sept 2004 - August 2008 & 5.243 & 2.864 \\
Post-crisis Sept 2008- December 2012 & -0.311 & $-27.855^{*}$
\end{tabular}

Note: The Phillips and Sul (2007) club clustering log t-test were run in OxEdit using the Gauss code programmed by Sul (2007). *Indicates rejection of the null hypothesis of convergence at the $5 \%$ significance level. The same Note applies for Tables 2-7.

Table 3. Convergence test for the interbank CID against Japan's rate

\begin{tabular}{lcc}
\hline \multicolumn{1}{c}{ Data series } & $\hat{b}$ & t-statistics \\
\hline One month interbank spread against Japan's rate & & \\
Pre-crisis Sept 2004 - August 2008 & -1.799 & $-35.095^{*}$ \\
Post-crisis Sept 2008- December 2012 & -1.040 & $-34.560^{*}$ \\
\hline Three month interbank spread against Japan's rate & & \\
Pre-crisis Sept 2004 - August 2008 & -1.824 & $-30.241^{*}$ \\
Post-crisis Sept 2008- December 2012 & -0.948 & $-36.649^{*}$ \\
\hline
\end{tabular}

Table 4. Convergence test for the interbank CID against the size-weighted average rate

\begin{tabular}{lcc}
\hline \multicolumn{1}{c}{ Data series } & $\hat{b}$ & t-statistics \\
\hline One month interbank spread against weighted average & & \\
Pre-crisis Sept 2004 - August 2008 & 1.293 & 24.150 \\
Post-crisis Sept 2008- December 2012 & 0.248 & 9.676 \\
\hline Three month interbank spread against weighted average & & \\
Pre-crisis Sept 2004 - August 2008 & 1.895 & 6.386 \\
Post-crisis Sept 2008- December 2012 & & \\
& & \\
\end{tabular}


Table 5. Convergence test for the bond CID against US's rate

\begin{tabular}{lcc}
\hline \multicolumn{1}{c}{ Data series } & $\hat{b}$ & t-statistics \\
\hline One -year bond spread against the US rate & & \\
Pre-bond Initiative: June 2005 - April 2008 & 2.865 & 2.235 \\
Post-bond initiative: May 2008- December 2012 & 0.164 & 5.897 \\
\hline Two-year bond spread against the US rate & & \\
Pre-bond Initiative: March 2007- April 2008 & -1.083 & $-114.665^{*}$ \\
Post-bond Initiative: May 2008- December 2012 & 2.423 & 2.155 \\
\hline
\end{tabular}

\section{Table 6. Convergence test for the bond CID against Japan's rate}

\begin{tabular}{lcc}
\hline \multicolumn{1}{c}{ Data series } & $\hat{b}$ & t-statistics \\
\hline One -year bond spread against the Japan's rate & -1.293 & $-56.383^{*}$ \\
Pre-bond Initiative: June 2005 - April 2008 & 0.103 & 4.848 \\
Post-bond initiative: May 2008- December 2012 & & \\
\hline Two-year bond spread against the Japan's rate & -0.845 & $-42.918^{*}$ \\
Pre-bond Initiative: March 2007- April 2008 & -0.017 & -0.395 \\
Post-bond Initiative: May 2008- December 2012 & & \\
\hline
\end{tabular}

Table 7. Convergence test for the bond CID against the size weighted rate

\begin{tabular}{lcc}
\hline \multicolumn{1}{c}{ Data series } & $\hat{b}$ & t-statistics \\
\hline One -year bond spread against the weighted average & & \\
Pre-bond Initiative: June 2005 - April 2008 & -0.891 & -0.931 \\
Post-bond initiative: May 2008- December 2012 & 0.167 & 1.881 \\
\hline Two-year bond spread against the weighted average & & \\
Pre-bond Initiative: March 2007- April 2008 & -1.572 & $-84.955^{*}$ \\
Post-bond Initiative: May 2008- December 2012 & 7.658 & 12.402 \\
\hline
\end{tabular}




\section{Table 8. Club Convergence Test}

\begin{tabular}{lcc}
\hline \multicolumn{1}{c}{ Data series : Interbank rates } & $\hat{b}$ & t-statistics \\
\hline One-month interbank CID against US rate & & -0.457 \\
Pre-crisis Sept 2004 - August 2008 & -0.358 \\
Club 1: CH, TH, MAL, SIN, JP, KO, INDO, PH, HK & \\
Post-crisis Sept 2008- December2012 & -0.101 \\
Club 1: CH, TH, MAL, SIN, JP, KO, INDO, PH, HK & $-6.781^{*}$ \\
\hline
\end{tabular}

Pre-crisis Sept 2004 - August 2008

Club 1: CH, TH, MAL, SIN, JP, KO, INDO, PH, HK

$5.243 \quad 2.864$

Post-crisis Sept 2008- December2012

Club 1: CH, TH, MAL, SIN, JP, KO, INDO, PH, HK

$-0.311 \quad-27.855^{*}$

One-month interbank CID against Japan's rate

Pre-crisis Sept 2004 - August 2008

Club 1: INDO, PH

$\begin{array}{ll}0.151 & 9.101 \\ 0.087 & 0.131 \\ -1.156 & -23.516 *\end{array}$

Post-crisis Sept 2008- December2012

Club 1:INDO, PH

$0.664 \quad 6.553$

Club 2: CH, TH, MAL, SIN, KO, HK

$0.096 \quad 2.003$

Three-month interbank CID against Japan's rate

Pre-crisis Sept 2004 - August 2008

Club 1: INDO, PH

0.177

9.877 


\begin{tabular}{lcc}
\hline Club 2: MAL, KO & 3.251 & 2.439 \\
Club 3: CH, TH, SIN & 0.195 & 2.705 \\
Divergent: HK & & \\
Post-crisis Sept 2008- December2012 & & 6.563 \\
Club 1: INDO, PH & 0.853 & 3.084 \\
Club 2: CH, TH, MAL, SIN, KO, HK & 0.103 & \\
\end{tabular}

\section{One-month interbank CID against the weighted average}

Pre-crisis Sept 2004 - August 2008

Club 1: SIN, JP, INDO, PH, HK

$2.487 \quad 1.373$

Divergent: CH, TH, MAL, KO

$-4.928 \quad-2.860^{*}$

Post-crisis Sept 2008- December2012

Club 1: SIN, JP, INDO, PH

$0.685 \quad 29.982$

Club 2: CH, TH, MAL, KO, HK

$0.684 \quad 0.429$

\section{Three-month interbank CID against the weighted average}

Pre-crisis Sept 2004 - August 2008

Club 1: SIN, JP, INDO, PH, HK

$1.841 \quad 0.810$

Divergent: CH, TH, MAL, KO

$-5.123-3.956^{*}$

Post-crisis Sept 2008- December2012

Club 1: SIN, JP, INDO, PH

$0.501 \quad 176.097$

Club 2: $\mathrm{CH}, \mathrm{TH}, \mathrm{MAL}, \mathrm{KO}$

$0.696 \quad 3.655$

Divergent: HK

Data series: Bond rates

$\hat{b} \quad$ t-statistics

One -year bond CID against the US rate 
Pre-bond Initiative: June 2005 - April 2008

Club 1: CH, TH, MAL, SIN, JP, KO, INDO, PH, HK

2.865

2.235

Post-bond initiative: May 2008- December2012

Club 1: CH, TH, MAL, SIN, JP, KO, INDO, PH, HK

$0.164 \quad 5.897$

Two-year bond CID against the US rate

Pre-bond Initiative: March 2007- April 2008

Club 1: TH, MAL, JP

$0.757 \quad 5.026$

Divergent: CH, SIN, KO, INDO, PH, HK

$-1.053$

$-48.769 *$

Post-bond Initiative: May 2008- December2012

Club 1: CH, SIN, JP, PH

1.522

4.022

Club 2: TH, MAL, KO, INDO, HK

$0.820 \quad 20.457$

One -year bond CID against Japan's rate

Pre-bond Initiative: June 2005 - April 2008

Club 1: INDO, PH

$0.908 \quad 14.285$

Club 2: MAL, KO

0.826

4.916

Club 3: TH, SIN, HK

0.010

0.260

Divergent: $\mathrm{CH}$

Post-bond initiative: May 2008- December2012

Club 1: SIN, INDO, PH, HK

$0.425 \quad 18.650$

Club 2: CH, TH, MAL, KO

$\begin{array}{ll}-0.081 & -1.032\end{array}$

Two-year bond CID against Japan's rate

Pre-bond Initiative: March 2007- April 2008

Club 1: INDO, PH

$0.158 \quad 1.790$

Club 2: MAL, KO

1.326

4.721

Divergent: CH, TH, SIN, HK

$-0.811$

$-26.775^{*}$

Post-bond Initiative: May 2008- December 2012

Club 1: CH, TH, MAL, SIN, KO, INDO, PH, HK

$-0.017$

$-0.395$ 


\section{One -year bond CID against the weighted average}

Pre-bond Initiative: June 2005 - April 2008

$-0.891$

$-0.931$

Club 1: CH, TH, MAL, SIN, JP, KO, INDO, PH, HK

Post-bond initiative: May 2008- December 2012

Club 1: TH, SIN, INDO, PH, HK

$0.867 \quad 35.483$

Divergent: CH, MAL, JP

$-3.734$

$-3.101^{*}$

\section{Two-year bond CID against the weighted average}

Pre-bond Initiative: March 2007- April 2008

Club 1: CH, TH, MAL, KO, INDO, PH

Divergent: SIN, JP, HK

Post-bond Initiative: May 2008- December 2012

Club 1: CH, TH, MAL, SIN, JP, KO, INDO, PH, HK

Note: the countries are China (CH), Thailand (TH), Malaysia (MAL), Singapore (SIN), Japan (JP), Korea (KO), Indonesia (INDO), Philippines (PH), Hong-Kong (HK) 
Table 9. $\beta$-convergence test results

\begin{tabular}{|c|c|}
\hline Variable & $\beta$-coefficient \\
\hline One-month interbank CID against the US (pre-crisis; post crisis) & $\begin{array}{ll}-0.16 * * * & -0.39 * * * \\
(0.03) & (0.04) \\
\end{array}$ \\
\hline Three-month interbank CID against the US (pre-crisis; post-crisis) & $\begin{array}{l}-0.10 * * * ;-0.40 * * * \\
(0.02)(0.04)\end{array}$ \\
\hline One-month interbank CID against Japan (pre-crisis; post-crisis) & $\begin{array}{ll}-0.20 * * * ; & -0.20 * * * \\
(0.04) & (0.03) \\
\end{array}$ \\
\hline Three-month interbank CID against Japan (pre-crisis; post-crisis) & $\begin{array}{l}-0.17 * * * ;-0.18^{* * *} \\
(0.03) \quad(0.027)\end{array}$ \\
\hline One-month interbank CID against the weighted average (pre-crisis; post-crisis) & $\begin{array}{l}-0.12 * * * ;-0.17 * * * \\
(0.025)(0.026)\end{array}$ \\
\hline Three-month interbank CID against the weighted average (pre-crisis; post-crisis) & $\begin{array}{l}-0.09 * * * ;-0.099 * * * \\
(0.022))(0.019)\end{array}$ \\
\hline One-year bond CID against the US (pre 2008; post 2008) & $\begin{array}{l}-0.04 ;-0.45^{* * *} \\
(0.026)(0.038)\end{array}$ \\
\hline Two-year bond CID against the US (pre 2008; post 2008) & $\begin{array}{ll}-0.33^{* * *} ;-0.31^{* * *} \\
(0.07) & (0.032) \\
\end{array}$ \\
\hline One-year bond CID against Japan (pre 2008; post 2008) & $\begin{array}{l}-0.30 * * * ;-0.15^{* * *} \\
(0.045) ;(0.025)\end{array}$ \\
\hline Two-year bond CID against Japan (pre 2008; post 2008) & $\begin{array}{l}-0.79 * * * ;-0.15^{* * *} \\
(0.10)(0.025)\end{array}$ \\
\hline One-year bond CID against the weighted average (pre 2008; post 2008) & $\begin{array}{l}-0.099 * * * ;-0.09 * * * \\
(0.028) \quad(0.019)\end{array}$ \\
\hline Two-year bond CID against the weighted average (pre 2008; post 2008) & $\begin{array}{l}-0.40^{* * * ;-0.06 * * *} \\
(0.11) \quad(0.016)\end{array}$ \\
\hline
\end{tabular}

Note: Standard errors are in parentheses. ***, **, * indicate $1 \%, 5 \%$ and $10 \%$ significance level respectively. 